\title{
DENTINE SIALOPHOSPHOPROTEIN SIGNAL IN DENTINEOGENESIS AND DENTINE REGENERATION
}

\author{
M.M. Liu ${ }^{1,2}$, W.T. Li ${ }^{1,3}$, X.M. Xia ${ }^{1,4}$, F. Wang ${ }^{5}$, M. MacDougall ${ }^{6}$ and S. Chen ${ }^{1}$ \\ ${ }^{1}$ Department of Developmental Dentistry, School of Dentistry, the University of Texas Health Science \\ Center at San Antonio, San Antonio, TX 78229, USA \\ ${ }^{2}$ Department of Endodontics, School of Stomatology, Tongii University, Shanghai, 200072, China \\ ${ }^{3}$ Department of Pathology, Weifang Medical University, Weifang, 261053, China \\ ${ }^{4}$ Department of Obstetrics and Gynaecology, Second Xiangya Hospital, Central South University \\ Changsha, 410011, China \\ ${ }^{5}$ Department of Anatomy, Fujian Medical University, Fuzhou, 350122, China \\ ${ }^{6}$ UBC Faculty of Dentistry, University of British Columbia, Vancouver, BC, V6T 1Z3, Canada
}

\begin{abstract}
Dentineogenesis starts on odontoblasts, which synthesise and secrete non-collagenous proteins (NCPs) and collagen. When dentine is injured, dental pulp progenitors/mesenchymal stem cells (MSCs) can migrate to the injured area, differentiate into odontoblasts and facilitate formation of reactionary dentine. Dental pulp progenitor cell/MSC differentiation is controlled at given niches. Among dental NCPs, dentine sialophosphoprotein (DSPP) is a member of the small integrin-binding ligand N-linked glycoprotein (SIBLING) family, whose members share common biochemical characteristics such as an Arg-Gly-Asp (RGD) motif. DSPP expression is cell- and tissue-specific and highly seen in odontoblasts and dentine. DSPP mutations cause hereditary dentine diseases. DSPP is catalysed into dentine glycoprotein (DGP)/sialoprotein (DSP) and phosphoprotein (DPP) by proteolysis. DSP is further processed towards active molecules.

DPP contains an RGD motif and abundant Ser-Asp/Asp-Ser repeat regions. DPP-RGD motif binds to integrin $\alpha \mathrm{V} \beta 3$ and activates intracellular signalling via mitogen-activated protein kinase (MAPK) and focal adhesion kinase (FAK)-ERK pathways. Unlike other SIBLING proteins, DPP lacks the RGD motif in some species. However, DPP Ser-Asp/Asp-Ser repeat regions bind to calcium-phosphate deposits and promote hydroxyapatite crystal growth and mineralisation via calmodulin-dependent protein kinase II (CaMKII) cascades.

DSP lacks the RGD site but contains signal peptides. The tripeptides of the signal domains interact with cargo receptors within the endoplasmic reticulum that facilitate transport of DSPP from the endoplasmic reticulum to the extracellular matrix. Furthermore, the middle- and COOH-terminal regions of DSP bind to cellular membrane receptors, integrin $\beta 6$ and occludin, inducing cell differentiation. The present review may shed light on DSPP roles during odontogenesis.
\end{abstract}

Keywords: Dentine, dental mesenchymal stem cells, dental caries, dentine regeneration, small integrinbinding ligand $\mathrm{N}$ linked glycoproteins, dentine sialoprotein, dentine glycoprotein, dentine phosphoprotein, dentine, dentine sialophosphoprotein.

*Address for correspondence: Shuo Chen, Department of Developmental Dentistry, School of Dentistry, University of Texas Health San Antonio, San Antonio, Texas 78229, USA.

Telephone number: +12105673511 Email: chens0@uthscsa.edu

Copyright policy: This article is distributed in accordance with Creative Commons Attribution Licence (http://creativecommons.org/licenses/by-sa/4.0/).

\begin{tabular}{llll}
\hline & List of Abbreviations & BSP & $\begin{array}{l}\text { bone sialoprotein } \\
\text { calmodulin-dependent protein } \\
\text { kinase II }\end{array}$ \\
ALP & alkaline phosphatase & CAMKII & clecranial dysplasia \\
Amg & amelogenin & CCD & Collagen type I alpha 1 \\
ASC & adult stem cell & DD & dentine dysplasia \\
BM & bone marrow & DD-I & DD type 1
\end{tabular}




\begin{tabular}{|c|c|}
\hline DD-II & DD type 2 \\
\hline DGI & dentineogenesis imperfecta \\
\hline DGI-II & DGI type 2 \\
\hline DGI-III & DGI type 3 \\
\hline DGP & dentine glycoprotein \\
\hline DMP1 & dentine matrix protein 1 \\
\hline DPC & dental pulp cell \\
\hline DPP & dentine phosphoprotein \\
\hline DPSC & dental pulp stem cell \\
\hline DSP & dentine sialoprotein \\
\hline DSPP & dentine sialophosphoprotein \\
\hline ECM & extracellular matrix \\
\hline ER & endoplasmic reticulum \\
\hline Erk1/2 & $\begin{array}{l}\text { extracellular signal-regulated } \\
\text { kinase } 1 / 2\end{array}$ \\
\hline Erv29p & ER-derived vesicles protein 29 \\
\hline ESC & embryonic stem cell \\
\hline FAK & focal adhesion kinase \\
\hline GFAP & glial fibrillary acidic protein \\
\hline HA & hydroxyapatite \\
\hline hBMSC & human bone marrow stem cell \\
\hline HSC & haematopoietic stem cell \\
\hline iPSC & induced pluripotent stem cell \\
\hline $\mathrm{KO}$ & knockout \\
\hline MAPK & mitogen-activated protein kinase \\
\hline MEPE & $\begin{array}{l}\text { matrix extracellular } \\
\text { phosphoglycoprotein }\end{array}$ \\
\hline MMP & matrix metalloproteinase \\
\hline MSC & mesenchymal stem cell \\
\hline $\mathrm{NCP}$ & non-collagenous protein \\
\hline Ocln & occludin \\
\hline Ocn & osteocalcin \\
\hline $\mathrm{OPN}$ & osteopontin \\
\hline Osx & osterix \\
\hline PP & phosphoryn \\
\hline RD & reactionary dentine \\
\hline rER & rough ER \\
\hline RGD & arginine-glycine-aspartic acid \\
\hline Runx2 & runt-related transcription factor 2 \\
\hline SAPK/JNK & $\begin{array}{l}\text { stress-activated protein kinase/Jun- } \\
\text { amino-terminal kinase }\end{array}$ \\
\hline SBE & Smad binding element \\
\hline SCAPs & $\begin{array}{l}\text { stem cells from the apical part of the } \\
\text { papilla }\end{array}$ \\
\hline SDS-PAGE & $\begin{array}{l}\text { sodium dodecyl sulphate- } \\
\text { polyacrylamide gel electrophoresis }\end{array}$ \\
\hline SHED & human exfoliated deciduous teeth \\
\hline SIBLING & $\begin{array}{l}\text { small integrin-binding ligand } \\
\text { N-linked glycoprotein }\end{array}$ \\
\hline Surf4 & surfeit locus protein 4 \\
\hline $\operatorname{Tg}$ & transgenic \\
\hline TGF- $\beta$ & transforming growth factor beta \\
\hline TLR & Tolloid-like \\
\hline UTR & untranslated region \\
\hline WHO & World Health Organization \\
\hline
\end{tabular}

\section{Introduction}

The tooth is a highly mineralised organ resulting from the interactions between the dental oral epithelial and mesenchymal cells. It is composed of enamel, dentine, cementum, soft connective tissues and periodontium (Fig. 1a) (Mitsiadis et al., 2015; Nanci, 2012). The dentine is a thick highly mineralised tissue layer (present underneath the enamel) consisting of dentinal tubules and inter-tubular dentine and acts as a secondary barrier against infections of the dental pulp cavity (Lopez-Cazaux et al., 2006). Dentineogenesis starts at the onset of odontoblast differentiation. Odontoblasts originate from neuralcrest-derived mesenchymal cells, which differentiate to form odontoblasts in specific temporal-spatial patterns, originating at the principal cusp tip and advancing toward the base of the teeth (Chen et al., 2008; Thesleff, 2003). Odontoblasts are mitotic cells organised as a layer of barrier cells along the edge between the dentine and dental pulp cavity. Odontoblasts synthesise and secrete the organic ECM proteins (Linde and Goldberg, 1993; MacDougall et al., 1997). Dentine is composed mostly of HA (70 \% by weight), $12 \%$ water as well as collagens and NCPs (Linde and Goldberg, 1993; MacDougall et al., 1997). Odontoblasts in odontogenesis and dental caries participate in the physiological primary and secondary dentine formation. Also, odontoblasts maintain the dentine metabolism throughout the life of the tooth and serve as the first line of defence against dentine pathogen invasion by RD (reparative, tertiary) formation at the dentine-pulp interface beneath the carious infected dentine region (Couve et al., 2014).

The dental pulp is a loose connective tissue and contains blood vessels with abundant capillaries and an innervated tissue under the odontoblast layer. Blood vessels facilitate the exchange of nutrients and waste products in the dental pulp (LopezCazaux et al., 2006; Tziafas et al., 2000). DPCs are a heterogeneous population retaining a source of MSCs (Tirino et al., 2012). Maintenance of a healthy, vascularised and innervated dental pulp is necessary for a healthy tooth and dental regeneration (Huang et al., 2018). In the dental pulp cavity, MSCs are known to dwell within peri-vascular microenvironments, termed niches (Kaukua et al., 2014; Shi and Gronthos, 2003; Sui et al., 2019), and other locations (Gronthos et al., 2000; Miura et al., 2003; Morsczeck et al., 2005; Seo et al., 2004). However, little is understood about exact localisations and signalling regulations of the niches (Bluteau et al., 2008). The role of specific local niches essential to regulate cell migration, differentiation and cell fate specification during developmental and reactional events of dentine is not well recognised (Ruch, 1985). Dental progenitors/MSCs are capable of differentiating into new odontoblast-like cells, which can form a dentine-like structure such as RD, for dentine repair after a dentine injury such as dental caries.

\section{Dental caries and its management}

Dental caries, the most prevalent chronic infectious disease globally, is a biological irretrievable 
impairment of vulnerable dental hard tissues due to acids produced by bacterial glycolysis of dietary carbohydrates (Baker et al., 2021). The WHO has defined the early childhood caries as a worldwide problem, with a prevalence between $60 \%$ and $90 \%$. In addition, more than $90 \%$ of all adults have experienced this disease (Bernabe et al., 2020; Griffin et al., 2008; Kazeminia et al., 2020). Tooth decay leads to dental pulpal infection, necrosis, loss of tooth function and vitality as well as eventual loss of the tooth. Various restorative materials have successfully been used to fill and replace injured or diseased dental tissues (Wang et al., 2020b). However, after restorative treatment, about $50 \%$ of cases demand revision in 5-10 years (Burke and Lucarotti, 2009; Chen et al., 2020). In addition, any traditional artificial restorative material might fail due to inappropriate physical, biocompatible and mechanical properties (Goldberg and Smith, 2004; Tziafas et al., 2000; Yang et al., 2020a). If the material pulls away from the cavity wall, a microleakage would form between the dentine layer and dental materials, causing secondary or recurrent caries (Askar et al., 2021; Goldberg and Smith, 2004; Tziafas et al., 2000). Therefore, despite several advances in dental restorative materials, it is required for new therapeutic restorative methods in dentistry to support a healthy dentition. Therapies using stem cells such as dental pulp MSCs, cell/ tissue engineering and other biomaterial components have successfully been reported for replacing or regenerating destroyed and injured dental tissues (Han et al., 2021; Saoud et al., 2016). For instance, Vidovic et al. (2017) showed that when pulpectomy is performed in animal models, a group of dental pulp progenitor cells/MSCs can migrate to the injured areas, differentiating into odontoblast-like cells, forming an RD. Consequently, the growth factor BMP2 enhances dental pulp cell differentiation into odontoblast-like cells, which synthesise and secrete dental ECMs, forming an RD in the injured areas (Nakashima, 2005; Ni et al., 2018). Besides BMP/ TGF- $\beta$ signalling, recent studies have demonstrated that Wnt/ $\beta$-catenin signalling induces progenitor cell/MSC growth and differentiation, promoting RD formation (Neves and Sharpe 2018; Zaugg et al., 2020). Furthermore, Han et al. (2021) reported that an artificial synthesised peptide, termed TVH-19, promotes human dental pulp cell differentiation and induces tertiary dentine formation in a rat model.

\section{Dental pulp MSCs}

Stem cells are characterised by both self-renewal and differentiation potential. The self-renewal of stem cells can occur by symmetric cell divisions, generating two daughter cells with the same fate, or asymmetric cell divisions, where one daughter cell is identical to the mother cell, while the other develops into a different cell type (Götz and Huttner, 2005).

Stem cells are classified as ESCs, iPSCs and ASCs. ESCs originate from the inner cell mass of the blastocyst prior to implantation. ESCs possess unlimited self-renewal potential and can generate all the body cell types. iPSCs, generated by inducing the expression of defined transcription factors in somatic cells, are pluripotent and can differentiate towards all cell types in given microenvironments. ASCs reside within different tissues such as the BM. Unlike ESCs and iPSCs, ASCs are limited in their potential to the cell types of the tissue they inhabit. Although stem cells normally remain in a quiescent, nondividing state, ASCs can proliferate and differentiate to replace damaged cells within their tissues and accelerate tissue healing following an injury (Cable et al., 2020; Pittenger et al., 1999; Yamanaka, 2020).

The BM contains numerous different cell types arising from HSCs, non-haematopoietic MSCs and other cell types, which are interconnected by a vascular and innervated network within the cavities of the BM. HSCs have the ability of self-renewal and differentiation into various cell types including erythrocytes, megakaryocytes, platelets, granulocytes, lymphocytes, osteoclasts, and dendritic cells (cells of the erythroid/myeloid lineages) and others. Subsequently, HSCs migrate to other haematopoietic or lymphoid organs giving rise to B lymphocytes, $\mathrm{T}$ lymphocytes, macrophages, and others. MSCs produce osteoblasts (boneforming cells), adipocytes (fat cells) and other cell types, while osteoclasts (bone-resorbing cells) share a monocytic origin with macrophages. MSCs display a variable self-renewal and differentiation potential (Friedenstein et al., 1970; Pittenger et al., 1999; Wilkinson et al., 2020). They have been widely characterised in vitro as expressing various markers such as STRO-1, CD146 or CD44 (Pittenger et al., 1999). STRO-1 is a cell surface marker of osteogenic precursors, CD146 and CD44 are pericyte and mesenchymal stem cell markers, respectively. MSCs have self-renewal ability and potentially differentiate into mesodermal lineages, therefore originating cartilage, bone, fat, skeletal muscle and connective tissues (Pittenger et al., 1999; Wang et al., 2020a). Endothelial progenitor/stem cells play a principal role in BM angiogenesis as they have clonogenic capability and can be mobilised into the peripheral blood system, differentiating into mature endothelial cells in newly formed blood vessels after tissue injury. Thus, endothelial stem cells derived from the BM represent a source for the body vasculogenesis and angiogenesis.

Dental pulp contains progenitor cells/MSCs able to differentiate into adipocytes, chondrocytes, odontoblasts, osteoblasts and other cell type in given environments. During dentineogenesis and tertiary dentine formation, dental pulp progenitors/ MSCs are able to differentiate into odontoblast-like and odontoblastic cells under appropriate signals (Gronthos et al., 2000; Miura et al., 2003; Sui et al., 2019). In a tooth, some cells can be either transitamplifying cells or progenitors and commit to terminal differentiation. These transit-amplifying cells and progenitors have a limited lifespan thus, 
they can only produce a tissue for a given time (Walker et al., 2019). By contrast, dental MSCs are selfrenewing and able to generate any of the tissues for their entire life span. In the dental pulp, dental MSCs include DPSCs, SHED and SCAP (Fig. 1b) (Gronthos et al., 2000; Miura et al., 2003; Sonoyama et al., 2008).

DPSCs were first isolated from human permanent third molar teeth and are the most common source of dental MSCs (Gronthos et al., 2000). DPSCs lack unique markers, therefore generic MSC markers such as STRO-1, CD146, CD105 and CD44 are used for the identification and isolation of DPSCs (Pittenger et al., 1999; Wang et al., 2020a). DPSCs can differentiate into odontoblasts (Gronthos et al., 2000), osteoblasts (d'Aquino et al., 2009), chondrocytes (Waddington et al., 2009), adipocytes (Gronthos et al., 2002; Waddington et al., 2009), myoblasts (Pisciotta et al., 2015) and neurogenic cells (Martens et al., 2014) in vitro and in vivo.

SHEDs were isolated from deciduous teeth, have fibroblastic features and express MSC specific markers including CD45, CD90, CD106, CD146, CD166 and STRO-1 but not haematopoietic and endothelial markers such as CD34 and CD31 (Miura et al., 2003). SHEDs have a high proliferation rate and can differentiate into adipogenic, chondrogenic, myogenic, neurogenic, odontogenic and osteogenic cells in vitro as well as induce formation of dentine and bone in vivo (Miura et al., 2003). SHEDs, neuralcrest-derived stem cells, also express neural cell markers such as nestin, beta III tubulin and GFAP as well as several pluripotent markers including Oct4 and Nanog (Chai et al., 2000; Miura et al., 2003; Yang et al., 2019; Yang et al., 2020b). SHEDs express more osteocyte markers such as ALP, collagen type I and Runx2 than do BM MSCs in vitro. SHEDs were transplanted into the subcutaneous tissue in immunodeficient mice and promoted bone repair through inhibition of osteoclast activity in vivo (Yamaza et al., 2010). They are also capable of differentiating into vascular endothelial cells and form functional blood vessels by up-regulation of MEK1/ERK signalling (Bento et al., 2013). Due to their deciduous teeth origin, SHEDs exhibit several features similar to DPSCs. However, their proliferation and differentiation capacity are higher than that of DPSCs and BM MSCs (Bluteau et al., 2008).

SCAPs isolated from apical papilla cells at the root apex of teeth, display high proliferation rates and demonstrate an increase of migratory and regenerative capacities compared with other dental MSCs (Sonoyama et al., 2008). SCAPs are easily obtainable from human third molars. As SCAPs can be derived from the primary teeth, they express primitive embryonic markers including Sox2, Oct3/4,
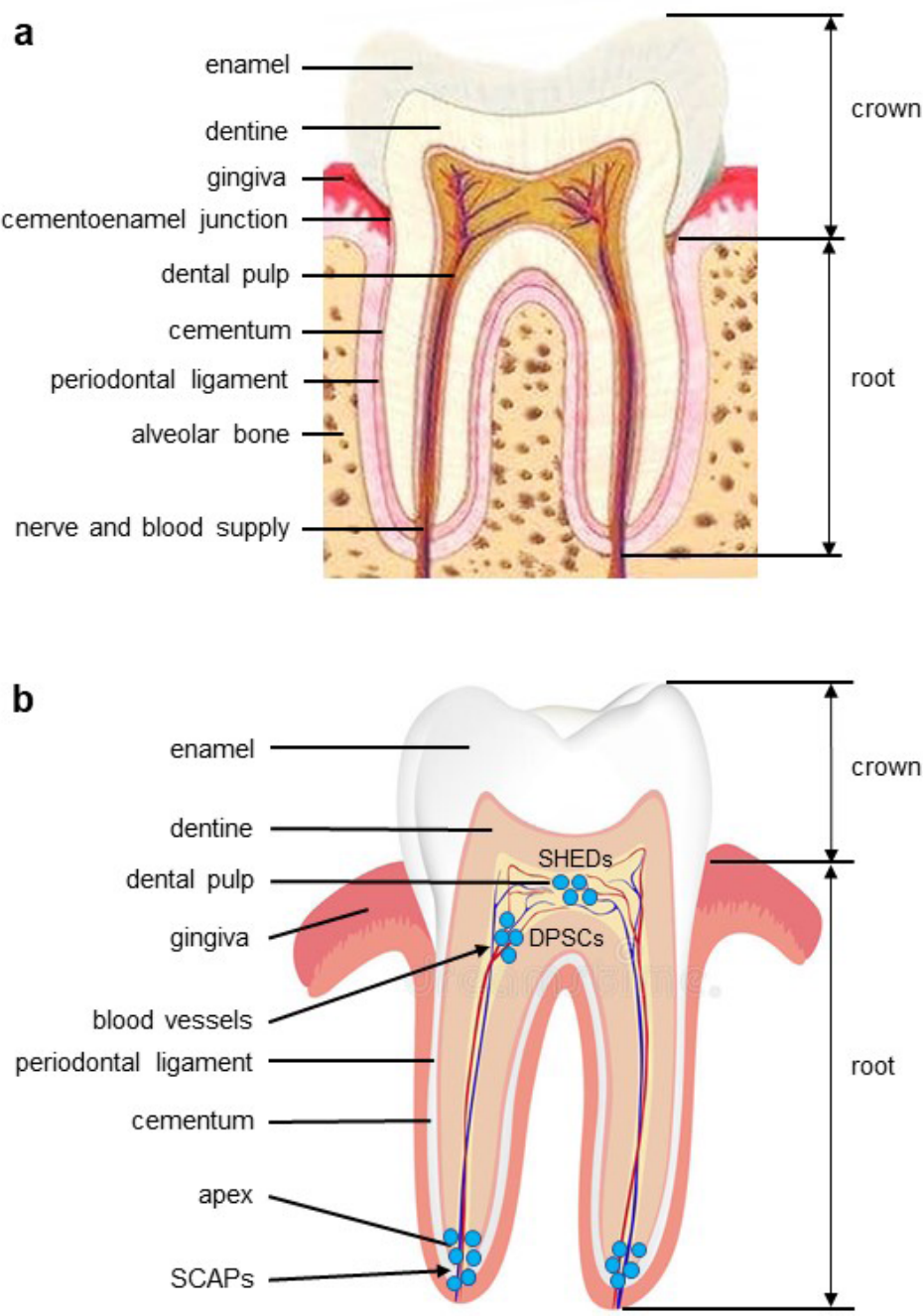

Fig. 1. Schematic representation of a molar and MSCs found in the teeth. (a) The crown of the tooth is covered with enamel, while the root is covered with cementum. The cementoenamel junction is located at the enamel and root. The root is surrounded by the alveolar bone through periodontal ligaments. The dentine surrounds the dental pulp. Nerves and blood vessels enter the dental pulp from the apical foramen of the tooth and provide nutrition and innervation to odontoblasts and dental pulp. (b) DPSCs; SCAPs; SHEDs. 
Nanog and others (Lee and Seo, 2016; Sonoyama et al., 2008). Among these markers, CD146 and STRO1 co-expression is related to early-MSC phenotype. Certainly, CD $146^{+} /$STRO- $1^{+}$SCAPs show superior colony-forming efficiency, with increased cumulative doubling compared with their counterpart (Nada and El Backly, 2018). CD24, another marker of the pluripotent population is considered to be a representative surface marker for SCAPs due to its absence in other dental MSCs (Kang et al., 2019). It is worth noting that the expression of the three markers CD146, STRO-1, CD24 declines with cell passaging, supporting their correlation with superior stemness. SCAPs are optimised for osteogenesis and odontogenesis; regarding that, SCAPs are considered to be odontoblast precursors in vivo (Du et al., 2020; Nada and El Backly, 2018). However, SCAPs are multipotent and give rise to mesenchymal cell lineages such as adipocytes and chondrocytes (Yang et al., 2020b). Taken together, SCAPs will hopefully gain a significant role in tissue repair and regeneration.

Besides dental MSCs (Gronthos et al., 2000; Miura et al., 2003), other MSC populations have been isolated from human dental tissues including the periodontal ligament (Seo et al., 2004) and the dental follicle (Morsczeck et al., 2005). Progenitors/stem cells isolated from the oral cavity express a group of mesenchymal markers, such as CD29, CD73, CD90 and CD105, and embryonic markers, including Sox2, Nanog and Oct4, and can differentiate into multiple cell lineages (Miran et al., 2016). Noticeably, some dental stem cells demonstrate more embryoniclike characteristics than those of BM and umbilical cord stem cells (Miran et al., 2016; Sui et al., 2019). Oral cavity MSCs are an important and valuable resource for dental and medical clinical/therapeutic applications. However, little is known about how progenitor cells/MSCs differentiate into specific mature cells, such as osteoblasts and odontoblasts, as well as which niches promote such differentiation.

\section{SIBLINGs and DSPP}

Niches can influence cell behaviour and fate (Méndez-Ferrer et al., 2020; Morrison and Spradling, 2008; Perry and Li, 2007). For instance, BM ECM influences osteoblast differentiation into osteocytes while dental pulp ECM governs dental progenitor cell/MSC differentiation into odontoblasts (Chen et al., 2005; Chen et al., 2007; Guo et al., 2009; Vijaykumar et al., 2020). Bone and dentine are highly mineralised tissues formed by osteoblasts and odontoblasts, which derive from mesenchymal cells. Both bone and dentine possess common characteristics and show similar features during mineralisation. During this process, odontoblasts and osteoblasts synthesise and secrete ECM proteins to form matrix-forming predentine and osteoid, respectively, which in turn are converted to bone and dentine. At the same time, the organic matrix of osteoid and predentine is composed of collagens and NCP proteins necessary for mineralisation of collagen fibres. The most
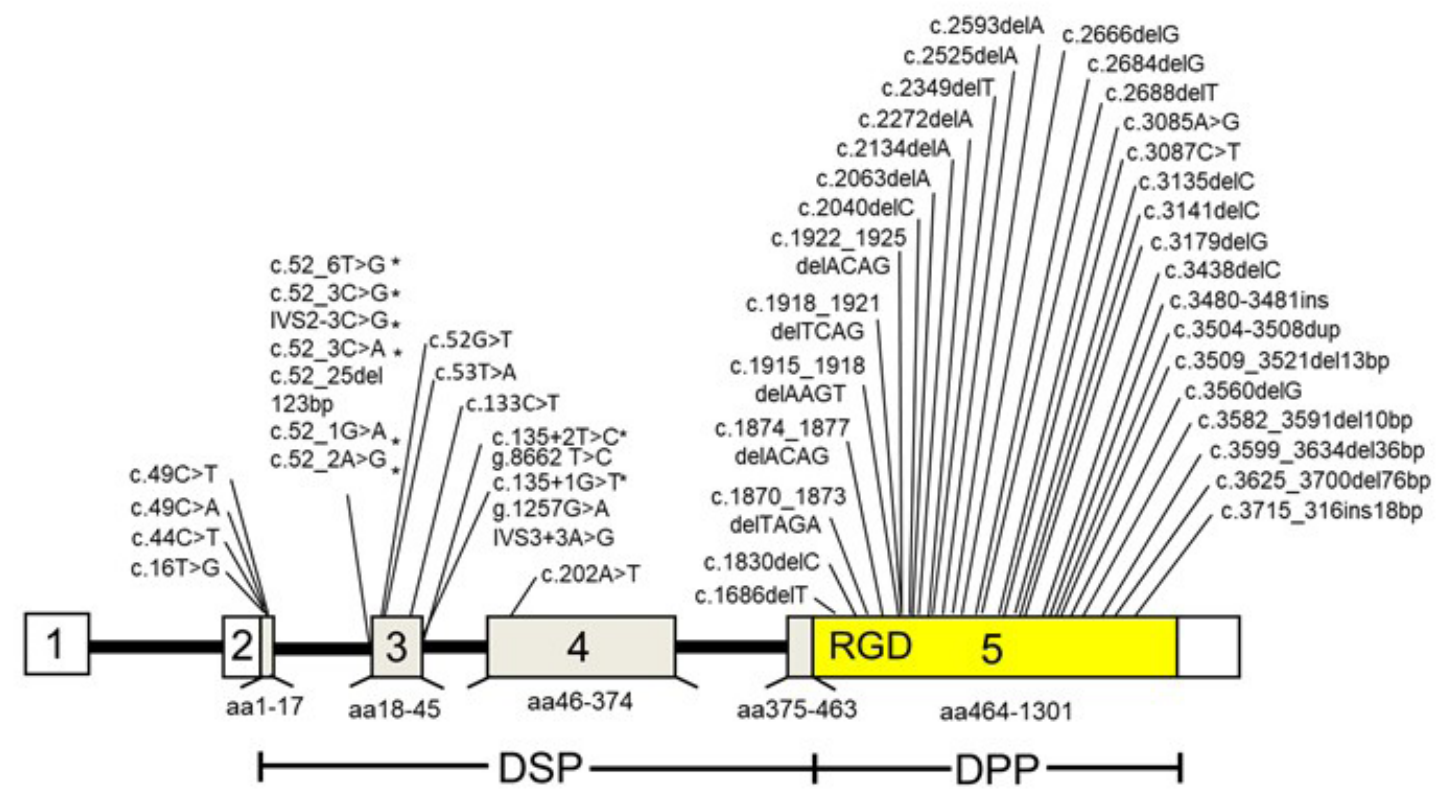

White boxes, untranslated regions

Gray boxes for coding regions of DSP Yellow box for coding region of DPP

Fig. 2. Diagram of DSPP mutations associated with genetic dentine diseases. The structure of the human $D S P P$ is shown. Exons are shown as boxes numbered 1-5, with the amino acids (aa) encoded by each exon indicated below. Introns are represented by lines. Locations of DSPP mutations are indicated. White colour indicates the 5' UTR, gray colour DSP sequences, yellow colour the DPP sequence. Asterisks show mutations affecting splice sites according to a splice-site recognition software (https://www.phenosystems.com/www/ index.php). c. = cDNA; g. = genomic; del = deletion; dup = duplication; ins = insertion; IVS = intervening sequence. 
common NCP proteins of bone and dentine include BSP, OPN, MEPE, DSPP and DMP1, belonging to the SIBLINGs family (Bellahcène et al., 2008; Fisher and Fedarko, 2003; MacDougall et al.,1997). SIBLING genes are located on chromosome 4 q21 in humans and chromosome $5 q$ in mice, sharing a similar exon structure. The presence of the RGD integrin-binding motifs enables them to trigger intracellular signals by initiating integrin-mediated signalling. Although bone and tooth show several common characteristics, the physical and biological functions of osteoblasts and odontoblasts exhibit several differences (Chen et al., 2005; Chen et al., 2009; Vijaykumar et al., 2020). The functions of the members of the SIBLINGs family in dentine and bone have been found through a linkage to human diseases and different genetic animal models. DSPP, $143 \mathrm{kDa}$, is the largest of the SIBLING proteins, with 1,301 amino acids in humans and plays essential roles in dentineogenesis (de La Dure-Molla et al., 2015). DSPP contains 4 introns and 5 exons (Fig. 2) (MacDougall et al.,1997). Unlike other SIBLING protein family members, DSPP spatial-temporal expression is mainly seen in pre-ameloblasts and odontoblasts during tooth development and formation (Chen et al., 2009; D'Souza et al., 1997) and weakly detected in osteoblasts and non-mineralised tissues (Fig. 3) (Chaplet et al., 2006; Qin et al., 2002). For example, DSPP protein expression in odontoblasts and dentine is about 400-fold higher than that in osteoblasts and bone (Qin et al., 2002). DSPP is transcribed from a single gene (MacDouall et al., 1997) but full-length DSPP has hardly been found in cells or tissues, whereas its cleavage products, DSP and DPP in mice, rats and humans as well as DSP, DGP and DPP in pigs are the most abundant NCPs in dentine and odontoblasts (Qin et al., 2001; Yamakoshi et al., 2005; Yuan et al., 2012).

DSP is composed of partial exon 2, exon 3, exon 4 and partial $\mathrm{NH}_{2}$-terminal region of exon 5 of DSPP, while DPP consists of most DSPP exon 5 (Fig. 2). DSPP is first processed into DSP/DGP and DPP (also termed dentine PP) by BMP1, TLR metalloproteinases and astacin proteases (Marschall and Fisher, 2010; Steiglitz et al., 2004; Tsuchiya et al., 2011). Then, DSP is further catalysed into small active molecules by MMP-2, -9 and -20 to expose cryptic binding sites into active molecules (Yamakoshi et al., 2006; Yuan et al., 2017). Mutations of the cleavage site between DSP and DPP regions result in DGI phenotypes in mice, indicating that DSPP needs to be cleaved into its active fragments, DSP and DPP (Zhu et al., 2012).

The porcine DGP has an 81 amino acid segment of DSPP (Ser ${ }^{392}$ to $\mathrm{Gly}^{472}$ ) located between DSP and DPP fragments. DGP contains 4 phosphorylated serine residues $\left(\operatorname{Ser}^{453}, \operatorname{Ser}^{455}, \operatorname{Ser}^{457}\right.$ and $\operatorname{Ser}^{462}$ ) and 1 glycosylated asparagine $\left(\mathrm{Asn}^{397}\right)$. DGP molecular weight is a $19 \mathrm{kDa}$ in SDS-APGE gel by Coomassie Brilliant Blue staining, that is decreased to $16 \mathrm{kDa}$ by glycopeptidase A digestion. The porcine DGP has the same number (12 each) of positively charged (Arg and
Lys) and negatively charged (Asp and Glu) residues. This pig DGP contains abundant Ser (12) and Gly (13). Lacking post-translational modifications, DGP has a calculated isoelectric point of 6.7. Due to containing 4 phosphorylated Ser and sialic acids, the modified DGP has an increased affinity for HA, which most likely facilitates the binding to dentine crystals. The identity of the porcine DGP amino acid sequence (NP_99842.1) is conserved, with 58 (81 \%) conserved amino acids in humans (F42472.1), 40 (49\%) in rats (L79813.1) and 38 (47 \%) in mice (C12787.1) (Yamakoshi et al., 2005). How DSPP is catalysed into the porcine DGP by proteinases and DGP functions during dentineogenesis are yet to be determined.

DSP and DPP play unique biological roles during tooth development (Paine et al., 2005; Suzuki et al., 2009). DSP or DPP mutations in humans are associated with DGI-II (OMIM 125490) and DGI-III (OMIM 125500) as well as DD-II (OMIM 125420) and DD-I (MIM 125400) (Fig. 2, Table 1,2). Those hereditary dentine disorders are the most common dentine genetic diseases. Estimated incidences of DGI in humans is $1 / 6,000-8,000$, while DD is $1 / 100,000$ (Witkop, 1975). DGI-II is characterised by pulpal calcification, opalescent discoloured dentition and bulbous crown shape as well as impaired odontoblast cell differentiation and delayed conversion of predentine to dentine (Fig. 4). DGI-III was originally regarded as a Brandywine isolate (Witkop, 1975) and a severe form of DGI-II with multiple dental pulp exposures and shell-like teeth. DD-II is similar to DGI-II in the deciduous dentition, but tooth discolouration is minimal and dental pulp cavities are thistle-tube shaped with pulp stones in the permanent dentition. In DD-I, teeth are normal in shape and form, as well as consistent in the deciduous and permanent dentitions. In some cases, colour of the teeth may exhibit a slightly amber discolouration. However, the roots are short, and the pulp obliteration causes a crescent-shaped pulpal remnant in the permanent dentition and a total pulpal obliteration in the deciduous dentition. Using mouse models, it was confirmed that Dspp is required for dentineogenesis, as homogenous null mice $\left(D s p p^{-/}\right)$show tooth deficiency similar to those seen in patients suffering from DGI and DD, with enlarged pulp cavities, a wide predentine zone, reduced dentine volume, hypomineralisation and dental pulp exposure (Fig. 4) (de La Dure-Molla et al., 2015; Sreenath et al., 2003).

SIBLING-RGD motifs are capable of binding to cell surface integrins in normal tissues and enhance cell adhesion, spreading, motility, proliferation, differentiation and survival via up-regulating kinase cascades and transcription factors. Also, the biological functions of SIBLINGs are regulated by proteolytic processing to uncover cryptic binding sites and expose functional domains, thus modulating cell adhesion and activity. For instance, OPN protein interacts with various integrins, such as $\alpha \mathrm{v} \beta 3, \alpha \mathrm{v} \beta 5$, $\alpha v \beta 1, \alpha 4 \beta 1, \alpha 8 \beta 1, \alpha 9 \beta 1$ and CD44 splice variants 
Table 1. Summary of DSP mutations associated with inherited dentine defects. ${ }^{a}$ Numbering assumes the A of the ATG start codon as nucleotide 1. Reference sequence NM_014208.3. c. = cDNA; g. = genomic; p. = protein; del = deletion; IVS = intervening sequence.

\begin{tabular}{|c|c|c|c|c|c|}
\hline Location cDNA $^{\mathrm{a}}$ & Protein & Ethnicity & Diagnosis & Mutation class & References \\
\hline \multicolumn{6}{|c|}{ Exon 2} \\
\hline $\begin{array}{l}\text { c. } 16 \mathrm{~T}>\mathrm{G} \\
\text { g. } 16 \mathrm{~T}>\mathrm{G}\end{array}$ & p.Y6D & Caucasian & DD-II & Missense & Rajpar et al., 2002 \\
\hline $\begin{array}{l}\text { c. } 44 \mathrm{C}>\mathrm{T} \\
\text { g. } 44 \mathrm{C}>\mathrm{T}\end{array}$ & p.A15V & Caucasian & DGI-II & Missense & Malmgren et al., 2004 \\
\hline $\begin{array}{l}\text { c. } 49 \mathrm{C}>\mathrm{A} \\
\text { g. } 49 \mathrm{C}>\mathrm{A}\end{array}$ & p.P17T & Chinese & DGI-II & Missense & Xiao et al., 2001 \\
\hline \multirow{3}{*}{$\begin{array}{l}\text { c. } 49 \mathrm{C}>\mathrm{T} \\
\text { g. } 49 \mathrm{C}>\mathrm{T}\end{array}$} & \multirow{3}{*}{ p.P17S } & Chinese & DGI-II & Missense & Zhang et al., 2007 \\
\hline & & Caucasian & DGI-II & Missense & Hart et al., 2007 \\
\hline & & Caucasian & DGI-II & Missense & McKnight et al., 2008 \\
\hline \multirow{2}{*}{$\begin{array}{c}\text { c. } 50 \mathrm{C}>\mathrm{T} \\
\text { g. } 50>\mathrm{T}\end{array}$} & \multirow{2}{*}{ p.P17L } & Chinese & DGI-II & Missense & Li et al., 2012 \\
\hline & & Korean & DGI-II & Missense & Lee et al., 2013 \\
\hline \multicolumn{6}{|c|}{ Intron 2} \\
\hline $\begin{array}{l}\text { c. } 52-6 \mathrm{~T}>\mathrm{G} \\
\text { g. } 1185 \mathrm{~T}>\mathrm{G} \\
\text { IVS2-6T }>\mathrm{G}\end{array}$ & p.V18_Q45del & Korean & DGI-II & Splice site & Lee et al., 2008 \\
\hline c. $52-3 C>$ G & p.V18_Q45del & Korean & DGI-II & Splice site & Kim et al., 2004 \\
\hline \multirow{2}{*}{$\begin{array}{l}\text { g. } 1188 \mathrm{C}>\mathrm{G} \\
\text { IVS2-3C }>\mathrm{G}\end{array}$} & & Korean & DGI-II & Splice site & Kim et al., 2004 \\
\hline & & Caucasian & DGI-II & Splice site & Kim et al., 2004 \\
\hline $\begin{array}{c}\text { c. } 52-3 C>A \\
\text { g.1194C > A } \\
\text { IVS2-3 }\end{array}$ & & Finnish & DGI-II & Splice site & Holappa et al., 2006 \\
\hline $\begin{array}{l}\text { c.52-25del23bp } \\
\text { IVS2-3C-A }\end{array}$ & & Chinese & DGI-II & Splice site & Wang et al., 2009 \\
\hline c.52-1G > A & & Chinese & DGI-II & Splice site & Liu et al., 2016 \\
\hline \multirow{2}{*}{ c. $52-2 \mathrm{~A}>\mathrm{G}$} & \multirow{2}{*}{ p.V18_Q45del } & Chinese & DGI-III & Splice site & Li et al., 2017 \\
\hline & & Thai & DGI-II & Missense & Porntaveetus et al., 2019 \\
\hline \multicolumn{6}{|c|}{ Exon 3} \\
\hline \multirow{6}{*}{$\begin{array}{c}\text { c. } 52 \mathrm{G}>\mathrm{T} \\
\text { g. } 1191 \mathrm{G}>\mathrm{T}\end{array}$} & \multirow{6}{*}{ p.V18F } & Chinese & DGI-II & Missense & Xiao et al., 2001 \\
\hline & & Korean & DGI-III & Missense & Kim et al., 2005 \\
\hline & & Caucasian & DGI-III & Missense & Kim et al., 2005 \\
\hline & & Chinese & DGI-II & Missense & Song et al., 2006 \\
\hline & & Finnish & DGI-II & Missense & Holappa et al., 2006 \\
\hline & & Chinese & DGI-II & Missense & Li et al., 2017 \\
\hline \multirow{3}{*}{$\begin{array}{c}\text { c. } 53 \mathrm{~T}>\mathrm{A} \\
\text { g. } 1192 \mathrm{~T}>\mathrm{A}\end{array}$} & \multirow{3}{*}{ p.V18D } & Japanese & DGI-II & Missense & Kida et al., 2009 \\
\hline & & Korean & DGI-II & Missense & Kim et al., 2009 \\
\hline & & Korean & DGI-II & Missense & Kim et al., 2011 \\
\hline \multirow{2}{*}{$\begin{array}{c}\text { c. } 133 \mathrm{C}>\mathrm{T} \\
\text { g. } 1272 \mathrm{C}>\mathrm{T}\end{array}$} & \multirow{2}{*}{ p.Q45X } & Chinese & DGI-II & Missense & Zhang et al., 2001 \\
\hline & & Chinese & DGI-II & Missense & Song et al., 2006 \\
\hline \multicolumn{6}{|c|}{ Intron 3} \\
\hline $\begin{array}{c}\text { c. } 135+2 \mathrm{~T}>\mathrm{C} \\
\text { g. } 8662 \mathrm{~T}>\mathrm{C}\end{array}$ & & Chinese & DGI-II & Splice site & Zhang et al., 2011 \\
\hline $\begin{array}{c}\text { c. } 135+1 G \\
\text { g. } 1275 G>A \\
\text { IVS3 + 1G > A }\end{array}$ & p.V18_Q45del & Chinese & DGI-II & Splice site & Xiao et al., 2001 \\
\hline c. $135+1 G>T$ & p.V18_Q45del & Caucasian & DGI-II & Splice site & McKnight et al., 2008 \\
\hline $\begin{array}{l}\text { c. } 135+3 A>G \\
\text { IVS3 }+3 A>G\end{array}$ & & Mongolian & DGI-II & Splice site & Bai et al., 2010 \\
\hline \multicolumn{6}{|c|}{ Exon 4} \\
\hline \multirow{2}{*}{$\begin{array}{c}\text { c. } 202 \mathrm{~A}>\mathrm{T} \\
\text { g. } 1474 \mathrm{~A}>\mathrm{T}\end{array}$} & \multirow{2}{*}{ p.R68W } & Caucasian & DGI-II & Missense & Malmgren et al., 2004 \\
\hline & & Finnish & DGI-II & Missense & Holappa et al., 2006 \\
\hline
\end{tabular}


Table 2. Summary of DPP mutations associated with inherited dentin defects. ${ }^{\text {a }}$ Numbering assumes the A of the ATG start codon as nucleotide 1. Reference sequence eNM_014208.3. ${ }^{\mathrm{b}}$ NSHL, familial nonsyndromic hearing loss. c. $=$ cDNA; p. $=$ protein; $\mathrm{fs}=$ frameshift; del = deletion; ins $=$ insert.

\begin{tabular}{|c|c|c|c|c|c|}
\hline Location cDNA $^{\mathrm{a}}$ & Protein & Ethnicity & Diagnosis & Mutation class & Reference \\
\hline \multicolumn{6}{|c|}{ Exon 5} \\
\hline c.1686delT & p.D562EfsX752 & Finnish & DD-II & Frameshift & Nieminen et al., 2011 \\
\hline \multirow{2}{*}{ c.1830delC } & \multirow{2}{*}{ p.S610RfsX704 } & \multirow{2}{*}{ French } & DD-II & Frameshift & Nieminen et al., 2011 \\
\hline & & & DD-II & Frameshift & McKnight et al., 2008 \\
\hline c.1870_1873delTCAG & p.S624TfsX687 & Caucasian & DD-II & Frameshift & McKnight et al., $2008^{\mathrm{b}}$ \\
\hline c.1874_1877delACAG & p.D625AfsX687 & Chinese & DDI-II & Frameshift & Li et al., 2017 \\
\hline c.1915_1918delAAGT & p.K639QfsX67 & Thai & DGI & Frameshift & Porntaveetus et al., 2017 \\
\hline c.1918_1921delTCAG & p.S640TfsX671 & Caucasian & DD-II & Frameshift & McKnight et al., 2008 \\
\hline c.1918_1921delTCAG & p.S640TfsX673 & Greek & DD-II & Frameshift & Nieminen et al., 2011 \\
\hline c.1922_1925delACAG & p.D641AfsX672 & Finnish & DD-II & Frameshift & Nieminen et al., 2011 \\
\hline c.2040delC & p.S680fsX1313 & Chinese & DD-II & Frameshift & Song et al., 2008 \\
\hline c.2063delA & p.D688VfsX626 & Finnish & DD-II & Frameshift & Nieminen et al., 2011 \\
\hline c.2134delA & p.S712AfsX602 & Turkish & DD-II & Frameshift & Lee et al., 2019 \\
\hline c.2272delA & p.S758AfsX554 & Caucasian & DGI-II/III & Frameshift & McKnight et al., $2008^{\mathrm{b}}$ \\
\hline c.2349delT & p.S783RfsX531 & Spanish & DDI-II & Frameshift & Nieminen et al., 2011 \\
\hline c.2525delG & p.S842TfsX471 & Caucasian & DGI-II/III & Frameshift & McKnight et al., $2008^{\mathrm{b}}$ \\
\hline c.2593delA & p.S865fsx1313 & Chinese & DDI-II & Frameshift & Song et al., 2008 \\
\hline c.2666delG & p.S889TfsX425 & Greek & DDI-II & Frameshift & Nieminen et al., 2011 \\
\hline \multirow{2}{*}{ c.2684delG } & \multirow{2}{*}{ p.S895fsx1313 } & Chinese & DDI-II & Frameshift & Song et al., 2008 \\
\hline & & Chinese & DDI-II & Frameshift & Li et al., 2017 \\
\hline c.2688delT & p.N896EfsX418 & Korean & DDI-II & Frameshift & Lee et al., 2010 \\
\hline c. $3085 \mathrm{~A}>\mathrm{G}$ & p.N1029D & Chinese & NSHLb & Missense & Li et al., 2018 \\
\hline c. $3087 \mathrm{C}>\mathrm{T}$ & p.N1029D & Chinese & NSHLb & Missense & Li et al., 2018 \\
\hline c.3135delC & p.S1045RfsX269 & Caucasian & DD-II & Frameshift & McKnight et al., 2008a \\
\hline c.3141delC & & Caucasian & DD-II & Frameshift & McKnight et al., 2008 \\
\hline c.3179delG & p.S1060TfsX254 & Korean & DD-II & Frameshift & Lee et al., 2019 \\
\hline c.3438delC & p.D1146fsX1313 & Chinese & DDI-II & Frameshift & Song et al., 2008 \\
\hline c.3480_3481insCTGCT & p.D1161LfsX155 & Korean & DD-II & Frameshift & Lee et al., 2019 \\
\hline c.3504_3508dup & p.D1170AfsX146 & Chinese & DDI-II & Frameshift & Yang et al., 2015 \\
\hline c.3509_3521del13bp & p.D1170AfsX139 & Chinese & DDI-II & Frameshift & Li et al., 2017 \\
\hline c.3546_3550delTAGCAinsG & p.D1182EfsX1312 & Chinese & DDI-II & Frameshift & Song et al., 2008 \\
\hline c.3560delG & p.S1187MfsX127 & Korean & DDI-II & Frameshift & Lee et al., 2011 \\
\hline c.3582_3591del10bp & $\begin{array}{c}\text { p.D1194EfsX117 } \\
\text { delCAGCAGCGAT }\end{array}$ & Finnish & DDI-II & Frameshift & Nieminen et al., 2011 \\
\hline $\begin{array}{c}\text { c.3599_3634del36bp } \\
\text { c.3715_3716ins18bp } \\
\text { del1160_1171 } \\
\text { ins1198_1199 }\end{array}$ & & American & DGI-III & Frameshift & Dong et al., 2005 \\
\hline c.3625_3700del76bp & p.D1209AfsX80 & Vietnamese & DDI-II & Frameshift & Nieminen et al., 2011 \\
\hline
\end{tabular}

(Bellahcène et al., 2008; Marschall and Fisher, 2008). OPN by thrombin cleavage separates the CD44- and integrin-binding domains, which in some cases promote adhesion over cell migration. Another example is the thrombin-cleaved $\mathrm{NH}_{2}$-terminal OPN segment that interacts with $\alpha v \beta 3$ and $\alpha v \beta 5$ integrins via the RGD motif (Bellahcène et al., 2008; Furger et al., 2003) or with $\alpha 4 \beta 1$ and $\alpha 9 \beta 1$ integrins via the cryptic SVVYGLR sequence (Rangaswami et al., 2006) and promotes cell adhesion and migration. The $\mathrm{COOH}-$ terminal region of OPN interacts with CD44 variant 6 (CD44v6) and/or variant 3 (CD44v3) by a heparin bridge (Teramoto et al., 2005). In addition, OPN is also catalysed by MMP-3 and MMP-7 and the cleaved
OPN domains promote cell adhesion and migration in vitro by activating $\beta 1$-containing integrins (Agnihotri et al., 2001). OPN is also a substrate for plasma transglutaminase factor IIIa and liver transglutaminase (Prince et al.,1991) and enhances cell adhesion, spreading and migration (Higashikawa et al., 2007). The RGD domain of DMP1 only binds to $\alpha \mathrm{V} \beta 3$, while BSP-RGD motif not only interacts with $\alpha \mathrm{V} \beta 3$, but also with $\alpha \mathrm{V} \beta 5$ and enhances cell adhesion and migration (Marschall and Fisher, 2008). DMP1 is a substrate of BMP1 and BMP1-generated DMP1 fragments have similar binding efficiency to the intact DMP1 protein in cell attachment and migration (Marschall and Fisher, 2008; Steiglitz et al., 2004). 


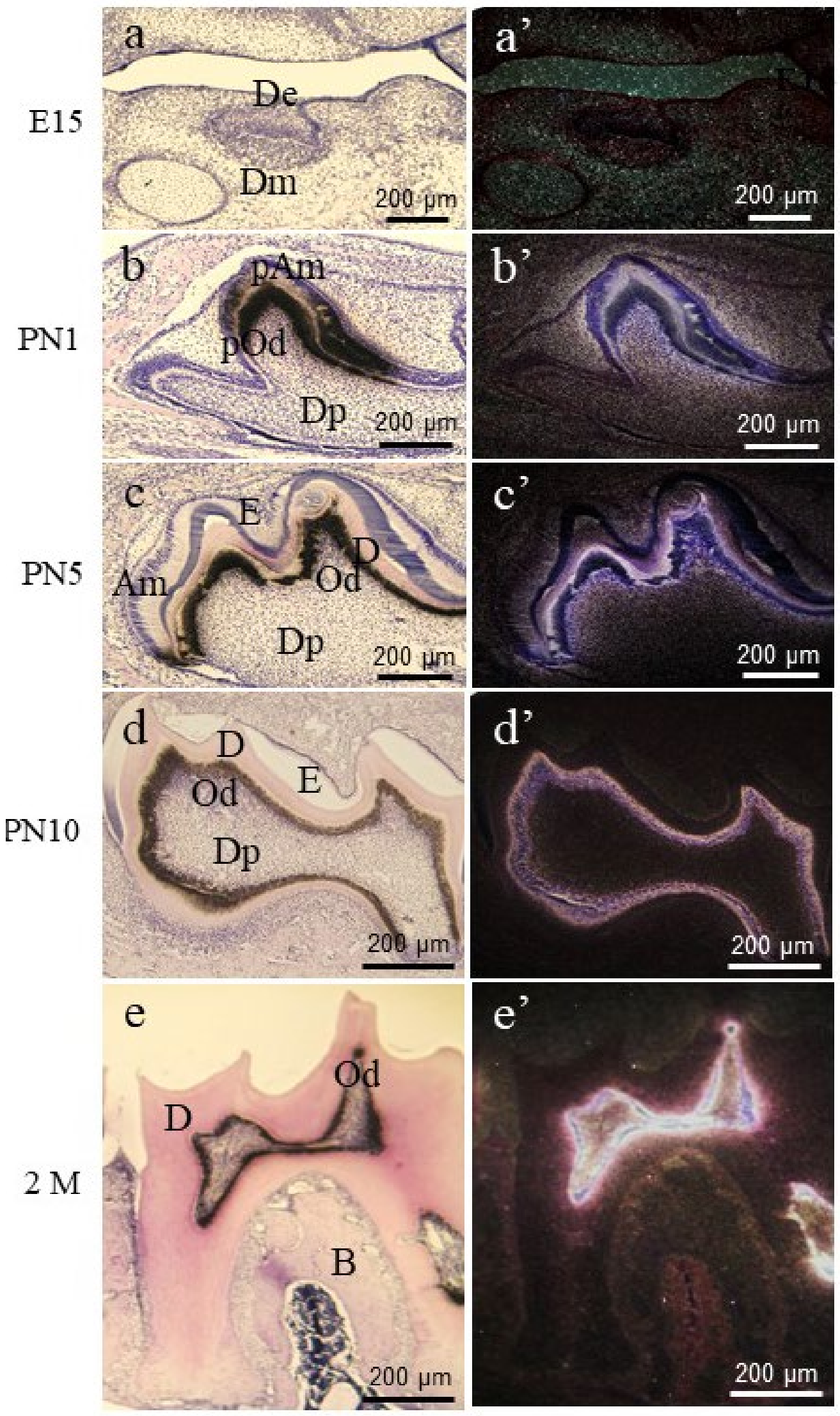

Fig. 3. DSPP expression pattern in developing mouse teeth from embryonic day 15 to postnatal month 2 . $\left(\mathbf{a}^{\prime}\right)$ DSPP mRNA expression was not seen in the dental and osteogenic mesenchyme as well as the dental epithelium at embryonic day 15 (E15). (b') At postnatal day 1 (PN1), DSPP expression was detected in preameloblasts, pre-odontoblasts and weakly in the dental pulp. $\left(\mathbf{c}^{\prime}-\mathbf{e}^{\prime}\right)$ DSPP expression was mostly restricted to odontoblasts from PN5 to 2 months (M) after birth while DSPP expression was barely seen in bones. (a-e) Brightfield images. Am, ameloblasts; B, bone; D, dentine; De, dental epithelium; Dm; dental mesenchyme, Dp, dental pulp; E, enamel; Od, odontoblasts; pAm, pre-ameloblasts; pOd, pre-odontoblasts. 


\section{DPP}

DPP contains an RGD domain at the $\mathrm{NH}_{2}$-terminal site, acting as a ligand and binding to integrin $\alpha \mathrm{V} \beta 3$. DPP-RGD/integrin- $\alpha \mathrm{V} \beta 3$ complex activates intracellular signalling pathways through upregulating $M A P K$, including $S A P K / J N K, E R K 1 / 2$ and p38 in human and mouse cells. Consequently, this complex up-regulates bone/dentine-related gene expression such as RUNX2, OSX, ALP, OCN and BSP in human and mouse cells as well as promotes cell differentiation and mineralisation in hBMSC, mouse osteoblastic cells (MC3T3-E1) and mouse fibroblastic (NIH3T3) cells (Jadlowiec et al., 2004; 2006). In addition, DPP-RGD induces phosphorylation of paxillin, FAK and of the transcription factor Elk-1 and up-regulates downstream gene transcription in mouse embryonic mesenchymal (C3H10T1/2) and primary dental pulp cells (Eapen et al., 2012) (Fig. 5). The flanking regions of the RGD motif influence binding of RGD to specific integrins and enhance cell adhesion and migration (Marschall and Fisher, 2008; Suzuki et al., 2014). However, unlike other SIBLING family members, 17 out of 37 DSPP genes from 37 species tested do not contain the RGD motif of DPP, indicating that the RGD domain within the DPP may be rudimental (Suzuki et al., 2016).

In addition to these common domains, only the DPP domain of DSPP contains abundant SerAsp or Asp-Ser repeat regions, which are the most phosphorylated regions of SIBLING protein and one of the most acidic proteins in numerous species such as human, rat and mouse (Jonsson et al., 1978; Suzuki et al., 2016). DPP binds to calcium ion and collagen type I, acting as an inductor of mineralisation in ECMs and inducing HA deposition and growth of vertebrate bones and teeth (He et al., 2005). DPP can interact with the cellular membrane (annexin 2 and 6) and facilitates calcium influx into cells (Alvares et al.,
2013) while functioning as a cell-penetrating peptide promoting cellular uptake of components attached to it and releasing different cargos intracellularly (Figueiredo et al., 2019; Ravindran et al., 2013). Additionally, DPP-DSS (Asp-Ser-Ser) repeat regions can facilitate intracellular $\mathrm{Ca}^{2+}$ release. This calcium flux promotes the activation of $\mathrm{Ca}^{2+} \mathrm{CaMKII}$. Activated CaMKII enhances the phosphorylation of the transcription factors Smad1/5/8 and phosphorylated Smad1/5/8 proteins are translocated to the nucleus and up-regulate Smad1/5/8 downstream gene expression as well as promote cell differentiation in murine pluripotent stem cells (C3H10T12) and hBMSCs (Eapen et al., 2013) (Fig. 5). Eapen et al. (2013) showed that the length of the Ser-Asp and/or Asp-Ser repeat regions varies among species but is not correlated with dentine hardness (Suzuki et al., 2016).

To analyse the relationship between length variations in Ser-Asp/Asp-Ser repeat regions and the role of DPP in matrix mineralisation, different lengths of the Ser-Asp/Asp-Ser repeat regions have been generated (Kobuke et al., 2015). Recombinant mouse Dpp deleted 63.5 Ser-Asp repeat regions, accounting for $36.5 \%$ of the length of the Ser-Asp repeat region, were generated and these peptides were able to induce calcium-phosphate precipitation similarly to the full length Dpp at the same concentration. In contrast, the inverted Dpp deleted 63.5 Ser-Asp repeat regions had no effect on the induction of calcium phosphate precipitation (Kobuke et al., 2015). The 8-repeat copy of Asp-Ser-Ser residues facilitates calcium-phosphate precipitation and HA crystal growth, promoting the remineralisation of demineralised human enamel and dentine tubule occlusion (Hsu et al., 2011). Dppmimetic peptide molecules upregulate the expression of bone/dentine-related genes including RUNX2, $A L P, D M P 1, O C N$ and collagen type I in human

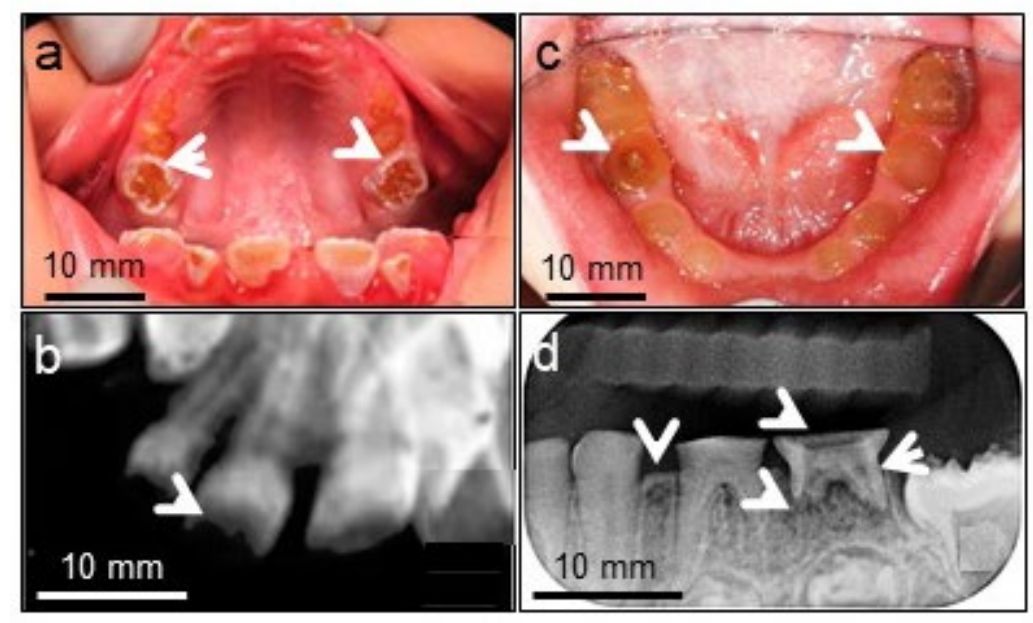

Fig. 4. Clinical photographs and radiographs from DGI-II patients. Clinical photograph of a 7 year-old boy showing (a) severe attritions (arrowheads). (b) Radiograph indicates severe enamel loss with decreased pulp space and reduced dental mineral density. (c) Intraoral photographs of a 5 year-old girl exhibiting severe attrition of the primary dentition to the gingiva level and teeth with yellow-brown colour and a translucent appearance (arrowheads). (d) Radiograph shows that dentine was thin, with severe occlusal attrition and periapical abscess (arrowheads). 
osteosarcoma (Saos-2) cells as well as promote cell differentiation (Gulseren et al., 2019). The biological function of Dpp was narrowed-down to 3 Asp-Ser-Ser repeat peptides that are able to facilitate calciumphosphate deposition on the human enamel surface and crystallographic structure of calcium-phosphate crystals in vitro (Chung et al., 2012).

For the in vivo study of the role of DPP, mice overexpressing Dpp transgenic gene driven by Col1 $\alpha 1$ promoter (Dpp-Col1 $\alpha 1 \mathrm{Tg})$ were crossed-bred with
$D s p p \mathrm{KO}\left(D s p p^{--}\right)$mice to generate $D s p p \mathrm{KO} / D p p$ Col1 $\alpha 1 \mathrm{Tg}$ mice (Zhang et al., 2018). Dspp KO/DppCol1 $\alpha 1 \mathrm{Tg}$ mice had an increase in dentine thickness and restored dentine mineral density compared with Dspp KO mice. Histochemistry showed that abnormal widening of the predentine was narrower in $D s p p \mathrm{KO} / D p p$-Col1 $\alpha 1 \mathrm{Tg}$ mice. Scanning electron microscopy analysis demonstrated that the structure of dentinal tubules in Dspp $\mathrm{KO} / \mathrm{Dpp}$-Col1 $\alpha 1 \mathrm{Tg}$ mice was better organised than that of Dspp KO mice.
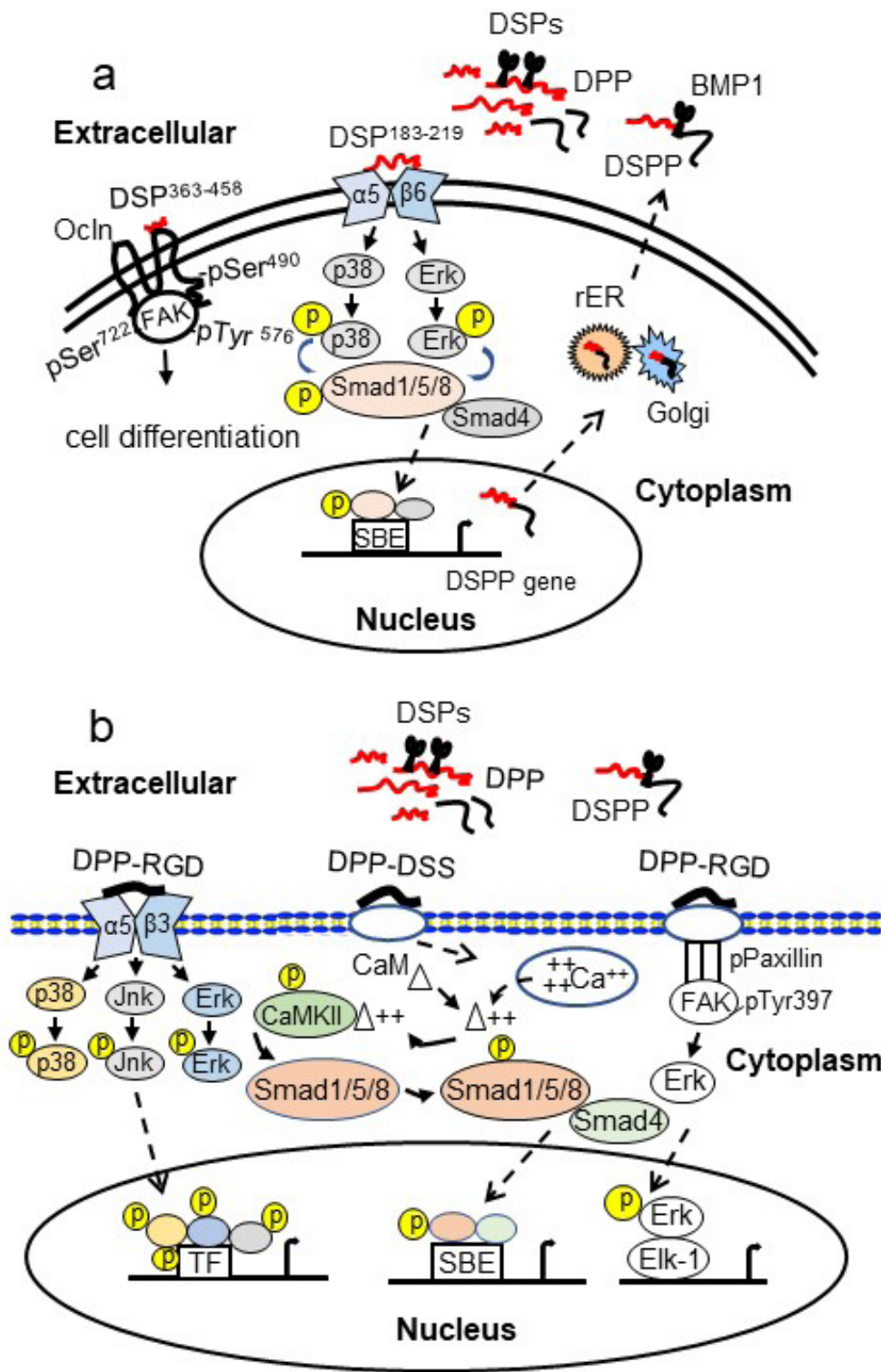

Fig. 5. Hypothetical model of DSPP signalling during dentineogenesis and dentine regeneration. (a) DSP $\mathrm{P}^{183-219}$ binds to integrin $\beta 6$ and forms a complex, activating phosphorylation of p38, Erk1/2 and Smad1/5/8. Phosphorylated Smad1/5/8 interact with Smad4. The complex is translocated into the nucleus. Phosphorylated Smad1/5/8 in coordination with Smad4 bind to SBEs in the DSPP regulatory region and activate DSPP transcription. On the other hand, $\mathrm{DSP}^{363-458}$ as a ligand interacts with the extracellular loop2 of Ocln ${ }^{194-241}$, stimulating Ocln phosphorylation at Ser ${ }^{490}$. Furthermore, the DSP-Ocln complex stimulates FAK phosphorylation at $\mathrm{Ser}^{722}$ and $\mathrm{Ty}^{576}$ and then induces dental mesenchymal cell differentiation and mineralisation. (b) DPP binds to integrin $\alpha 5 \beta 3$ through its RGD domain. DPP- $\alpha 5 \beta 3$ activates MAPK signal pathway and up-regulates gene expression and cell differentiation. The RGD domain of DPP phosphorylates paxillin and FAK at Tyr ${ }^{397}$. Phosphorylated FAK activates Erk and phosphorylated Erk is translocated into the nucleus and activates transcription factor Elk-1 and downstream gene expression. In addition, the DSS repeat region of DPP mediates intracellular calcium store flux and triggers CaMKII activation, resulting in Smad1/5/8 signalling cascade. DSS, Asp-Ser-Ser; RGD, Arg-Gly-Asp. 
Dentine mineral deposition rate in $D s p p \mathrm{KO} / D p p$ Col1 $\alpha 1 \mathrm{Tg}$ mice was significantly enriched compared to that of Dspp KO mice as analysed by double fluorochrome labelling. The overexpression of Dpp partially rescued the dentine deficiency in Dspp KO mice, indicating that Dpp may facilitate dentine development during dentineogenesis. In contrast, the body weight of $D p p$-Col1 $\alpha 1 \mathrm{Tg}$ mice was lower compared to that of wild type mice. Moreover, both short and long bones were shorter in Dpp-Col1 $\alpha 1$ $\mathrm{Tg}$ mice compared to that of wild type mice. DppCol1 $\alpha 1 \mathrm{Tg}$ mice presented reduced trabecular bone formation and exhibited narrow proliferative and chondroblast layers in long bones. Histochemistry analysis demonstrated that the proliferative zone of long bones in Dpp-Col1 $\alpha 1 \mathrm{Tg}$ mice was characterised by reduced cell proliferation and increased gene expression of chondroblast differentiation markers such as type II collagen (a marker of proliferating chondrocytes), type $X$ collagen (a marker of hypertrophic chondrocytes) and proteoglycan, but there were no obvious defects in chondrocyte differentiation (Zhang et al., 2016). Transgenic mice of an overexpression of $D p p$ driven by the mouse $A m g$ promoter (Dpp-Amg Tg) were generated. DppAmg Tg mice showed a pitted and chalky enamel with nonuniform thickness that tended to wear more easily. In mice, $D p p-A m g$ transgene results in disruptions of the prismatic enamel structure and weakened enamel with uneven thickness (Paine et al., 2005; White et al., 2007). The reasons for the different effects of Dpp on different tissue development and formation remain unclear. A reason might be that the biological mechanisms of Dpp are cell- and tissue-specific. Spatial-temporal expression of Dspp is detected in preodontoblasts and preameloblasts at early stages of tooth development. During mouse tooth formation at postnatal stages, Dspp expression is barely detected in ameloblasts, but continuously seen in odontoblasts, predentine and dentine, maintaining odontoblast and dentine metabolism and homeostasis (Fig. 3) (Chen et al., 2009; D'Souza et al., 1997). However, Dspp is weakly expressed in osteoblasts, chondrocytes and bones (Chen et al., 2009; Qin et al., 2002). This suggests that a dose-dependent tuning of Dspp expression plays important roles in cell- and tissue-biological activity and behaviour. For instance, Runx2 is a key factor necessary for osteoblast differentiation and bone formation (Ducy et al., 1997). RUNX2 mutations in humans are related to CCD, with affected subjects displaying short stature, late closure of fontanels and sutures, aplasia of clavicles, hypertelorism, low nasal bridge and dental defects including tooth hypoplasia supernumerary teeth and abnormal tooth eruption (Lee et al., 1997). Runx2 is expressed by dental mesenchymal cells at the early stages and downregulated in odontoblastic cells at the later stages during odontogenesis (Chen et al., 2009). Runx2 stimulates Dspp expression in mouse preodontoblastic cell lines but represses its expression in mouse odontoblastic cells (Chen et al., 2005).
Run $x 2^{-/-}$mice present impairment of tooth formation, with progression only to the cap/early bell stages of tooth development. The teeth in Runx $2^{-/-}$mice are misshapen, severely hypoplastic and lack odontoblast and ameloblast differentiation, while exhibiting loss of normal dentine and enamel matrices (D'Souza et al., 1999). In contrast, in Runx $2 \mathrm{Tg}$ mice, odontoblasts lose their normal columnar shape and dentine is surrounded by odontoblasts that are flat or/and cuboid in shape. In Runx2 Tg mice, dentine is thin and retains lacunae, which display osteoblast and bone-canaliculi-like structures. Structure of dentinal tubules and pre-dentine is invisible. Moreover, collagen type I expression is decreased and Dspp expression is undetectable (Miyazaki et al., 2008). Therefore, Runx2 function is related to cell- and tissue-type-specific or dependent on the stages of cytodifferentiation during tissue development.

\section{DSP}

DSP lacks an RGD domain and Ser-Asp/Asp-Ser repeat regions (MacDougall et al 1997; Suzuki et al., 2016). Many DSPP mutations occur in the DSP region (Fig. 2, Tables 1,2). DSP and peptides derived from it are able to regulate gene expression, protein phosphorylation and induce dental primary/stem cell differentiation (Lee et al., 2012; Ozer et al., 2013).

The starting site of DSP contains the signal peptides, which are required for intracellularly trafficking of DSPP from the rER to the ECM. Point mutations of the signal peptides such as Tyr 6 to Asp, Ala 15 to Val, Pro 17 to Leu and Val 18 to Asp together with frameshift mutations resulting in longer mutant hydrophobic domains of DSPP are associated with DD-II, DGI-II and DGI-III (Fig. 2, Table 1,2). In a mouse model, an amino acid on Pro 19 of the signal peptides of Dspp was substituted by an amino acid on Leu 19 (Liang et al., 2019). The mutant mice

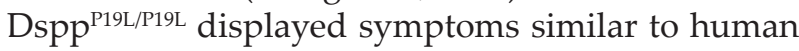
DGI-II and DGI-III, showing enlarged dental pulp chambers in mutant young mice and smaller dental pulp chambers in older mutant mice. These mutant mice exhibited an increase in enamel attrition and an undue deposition of peritubular dentin. Dspp $p^{\text {P19L/ }}$ ${ }^{P 19 L}$ mice presented a decrease in Dspp expression in odontoblasts as compared to the wild type mice. The secretion of the mutated Dspp was impaired and the mutant Dspp protein accumulated within the rER. The traffic mechanisms of Dspp protein from rER to ECM related to the mutations in the signal peptides associated with DGI and DD are not completely known. Recently, Yin et al. (2018) found that Surf4 (also named Erv29p) is the cargo receptor, which has a high affinity for binding the triple amino acids, IPV, within the signal peptides of DSPP but weakly binds the mutant amino acids of the signal peptides. The wild type DSPP is transported from the rER lumen to the ECM. Specific alterations in a single amino acid of the tripeptide of Dspp result in inadequate aggregate formation of Dspp within the rER and failure to efficiently transport Dspp out of 
the rER. The mutant signal peptide(s) of Dspp protein accumulate in the rER lumen, forming damaging aggregates and degradation by proteinases within rER (Yin et al., 2018).

DSP is an ECM protein that activates intracellular signalling pathways when dental cells are treated with it (Lee et al., 2012; Ozer et al., 2013). How DSP domain and its cleaved products facilitate intracellular signalling is unknown. Dsp protein was used as a bait for seeking its partner(s) through screening a dental cell protein library and it was found that Dsp acts as a ligand and interacts with 4 cellular membrane proteins including Ocln, integrin $\beta 6$, CD105 (endoglin) and collagen type IV (Li et al., 2017; Wan et al., 2016). Dsp ${ }^{183-219} 36$ amino acids are sufficient for interacting with the cellular membrane receptor integrin $\beta 6$. Dsp-integrin $\beta 6$ complex stimulates p38 and Erk1/2 phosphorylation and phosphorylated transcription factors Smad1/5/8 (pSmad1/5/8). pSmad1/5/8 interacts with Smad4 and both are translocated into the nucleus, bind to Dspp regulatory region, upregulate $D s p p$ transcription and have a positive feedback on Dspp expression and odontoblast cell homeostasis. Also, Dsp ${ }^{183-219}$ peptide promotes dental cell spreading, migration, proliferation and differentiation. On the other hand, the $\mathrm{COOH}$-terminal domain of $\mathrm{Dsp}^{363-458}$ binds to the second loop ${ }^{194-241}$ of Ocln, which is an integral membrane protein (Cong and Kong, 2020). Dsp domain phosphorylates Ocln on $\operatorname{Ser}^{490}$ and FAK on Ser $^{722}$ and $\mathrm{Tyr}^{576}$ through binding of Ocln to FAK. Dsp ${ }^{363-458}$ facilitates mouse dental papilla mesenchymal and human dental pulp stem cell differentiation and mineralisation. Furthermore, in an in vivo study, Dsp ${ }^{363-458}$ was mixed with agarose beads (Dsp-beads) and the Dsp-beads compound was implanted into mouse dental pulp chambers. The histological analysis showed that in Dsp-beads-treated mice, dental pulp mesenchymal cell proliferation and cell differentiation were significantly improved around the Dsp-beads compound compared to that of the control mice. The dental pulp mesenchymal cells in the Dsp-beads-treated groups secreted dental ECMs and formed a layer between the dental pulp chamber and resin. More interestingly, there were a lot of newly formed blood vessels and less inflammatory cells around the Dsp-beads, along with the dental pulp mesenchymal cells and blood vessels, which migrated into the Dsp-beads. This study indicated that the Dsp $\mathrm{Ds}^{36458}$ is capable of inducing dental mesenchymal cell proliferation, cell differentiation and vasculogenesis (Fig. 5) (Li et al., 2017).

For the in vivo study of the biological role of DSP, overexpression of $D s p \mathrm{Tg}$ mice driven by the mouse $D s p p$ promoter (Dsp-Dspp Tg) was generated (Suzuki et al., 2009). Dsp-Dspp Tg mice were crossed-bred with the $D s p p^{-/}$mice. $D s p p^{-/-} / D s p-D s p p$ Tg mice resulted in partial rescue of restored predentine width, decrease of frequent dental pulp chamber exposure and partial recovery in dentine volume compared to Dspp KO mice. However, no rescue of dentine mineral density was observed in these $D s p p^{-1-} / D s p-D s p p$ Tg mice. This study implies that Dsp is related to the initiation of dentine mineralisation. In addition, overexpression of the Dsp Tg mice driven by the mouse Amg promoter (Dsp-Amg Tg) causes significantly and uniformly increased enamel hardness and an increased rate of enamel mineralisation but did not significantly alter enamel morphology. These studies demonstrated that Dsp significantly contributes to the physical properties of the dentine-enamel junction and facilitates enamel formation (Paine et al., 2005; White et al., 2007). In contrast, Dsp driven by Col1 $\alpha 1$ promoter (Dsp-Col1 $\alpha 1 \mathrm{Tg}) \mathrm{Tg}$ mice were crossedbred with Dspp KO mice to generate Dspp KO/DspCol1 $\alpha 1 \mathrm{Tg}$ mice (Gibson et al., 2013). Unexpectedly, dentine of Dspp KO/Dsp-Col1 $\alpha 1 \mathrm{Tg}$ mice was much thinner, more poorly mineralised and remarkably disorganised than that of $D s p p^{-/-}$mice. Dspp KO/DspCol1 $\alpha 1 \mathrm{Tg}$ mice displayed more severe dentine defects than $D s p p^{-/-}$mice. Furthermore, Dspp KO/Dsp-Col1 $\alpha 1$ $\mathrm{Tg}$ mice resulted in severely worse periodontal defects than that of Dspp KO mice and a greater decrease of alveolar bone, more remarkably altered canalicular structures around the osteocytes, less cementum, more radical migration of the epithelial attachment towards the apical direction and more severe inflammation in molar furcation region than that of Dspp KO mice (Gibson et al., 2014). Overall, this suggests that the Dsp mediates an inhibitory role in periodontium formation. The different Dsp effects on hard tissue development and formation may rely on the control of given tissue gene promoters.

\section{Conclusions and future perspectives}

The present review provides a brief overview of DSPP expression, proteolysis, pathophysiology and biological functions of the cleaved products, DSP/DGP and DPP, based on the recent literature. Dentine is a highly mineralised tissue and derives from odontoblasts. When dentine is injured, such as in cases of pulpotomy and dental caries, dental pulp progenitors/MSCs can migrate to the injured areas and differentiate into odontoblast-like cells (Vidovic et al., 2017). The differentiation of the dental pulp progenitors/MSCs is controlled at the given niches (Méndez-Ferrer et al., 2020; Morrison and Spradling, 2008). During dentineogenesis, odontoblasts synthesise and secrete dental ECMs, which bind to calcium-phosphate, finally forming predentine and dentine. Dental ECMs are composed of collagens and NCPs (MacDougall et al., 1997). Among NCPs, DSPP expression is highly visible in odontoblasts and dentine (Fig. 3) (Chen et al. 2009; D'Souza et al.,1997). DSPP is catalysed into DSP/DGP, DPP by BMP1 and TLR proteinases (Marschall and Fisher, 2010; Yamakoshi et al., 2006). Mutations of DSP and DPP domains are associated with DD-I, DD-II, DGI-II, DGIIII and the most common genetic dentine diseases (Fig. 2, Table 1,2). DSP and DPP play unique roles 
during odontogenesis. DSP promotes the initial effect on early dentine development while DPP is related to HA crystal growth and mineralisation (Suzuki et al., 2016). DSP is a ligand and facilitates intracellular signalling via its cellular membrane receptors, integrin $\beta 6$ and Ocln as well as induces dental pulp/ MSC cell differentiation and mineralisation. Dsp ${ }^{183}$ ${ }^{219}$ - $\beta 6$ signal up-regulates Dspp expression, dental cell proliferation and differentiation via p-p38-pErkSmad1/5/8 signal pathways, while Dsp ${ }^{363-458}$-Ocln complex promotes dental mesenchymal cell/MSC differentiation and biomineralisation through FAK cascades (Fig.5a). Overexpression of Dsp partially rescues dentine defects in Dspp KO mice (Suzuki et al., 2009). In addition, DPP-RGD activates downstream gene expression and cell differentiation through integrin-MAPKs and paxillin-FAK signal pathways. Moreover, DPP contains Ser-Asp/Asp-Ser repeat regions, which mediate intracellular calcium store flux and trigger CaMKII-Smad1/5/8 activations, facilitating cell differentiation and mineralisation (Fig.5b). Dpp overexpression partially rescues dentine defects in Dspp KO mice (Zhang et al., 2018). Nevertheless, overexpression of $D s p$ or $D p p$ driven by the given gene promoter(s) results in impairment of certain tissues' development (Gibson et al., 2014; White et al., 2007). How DSP and DPP play dual roles in different tissues is not completely understood and needs to be further studied. Although biological roles of DSPP have made the advanced achievements in odontoblast differentiation and mineralisation during tooth development, mechanisms of DSPP during tooth development and formation remain still unknown. For instance, where cleavages of DSPP occur in cytoplasm and/or ECMs needs to be further investigated. Differences of three-dimensional structures between wild type and mutant DSPP and its cleaved products have not been described and need to be studied. Control of the spatial-temporal cell- and tissue-specific expression of DSPP is not completely understood although DSPP expression is controlled by several growth factors, transcriptional factors and materials (Chen et al., 2008; Suzuki et al., 2016). However, understanding the mechanisms of DSPP spatial-temporal expression in odontoblastic cells at different stages during tooth formation and progenitor cell/MSC differentiation to odontoblasts may be a potential novel avenue during dentine development and regeneration.

\section{Acknowledgments}

This study was funded by the National Institute of Health (NIH)/National Institute of Dental Craniofacial Research (NIDCR), R01DE019802 and pilot research award from the University of Texas Health San Antonio (UTHSA) School of Dentistry, TX, USA. All authors contributed to the planning, writing, critical reading and editing of the manuscript. We thank Ms. Aries Okungbowa-Ikponmwosa for editing the manuscript. The authors declare that there are no conflicts of competing and financial interests.

\section{References}

Agnihotri R, Crawford HC, Haro H, Matrisian LM, Havrda MC, Liaw L (2001) Osteopontin, a novel substrate for matrix metalloproteinase-3 (stromelysin-1) and matrix metalloproteinase-7 (matrilysin). J Biol Chem 276: 28261-28267.

Alvares K, Stern PH, Arthur Veis A (2013) Dentin phosphoprotein binds annexin 2 and is involved in calcium transport in rat kidney ureteric bud cells. J Biol Chem 288: 13036-13045.

Askar H, Krois J, Göstemeyer G, Schwendicke F (2021) Secondary caries risk of different adhesive strategies and restorative materials in permanent teeth: systematic review and network meta-analysis. J Dent 104: 103541. DOI: 10.1016/j.jdent.2020.103541.

Bai H, Agula H, Wu Q, Zhou W, Sun Y, Qi Y, Latu S, Chen Y, Mutu J, Qiu C (2010) A novel DSPP mutation causes dentinogenesis imperfecta type II in a large mongolian family. BMC Med Genet 11: 23. DOI: 10.1186/1471-2350-11-23.

Baker JL, Morton JT, Dinis M, Alvarez R, Tran NC, Knight R, Edlund A (2021) Deep metagenomics examines the oral microbiome during dental caries, revealing novel taxa and co-occurrences with host molecules. Genome Res 31: 64-74.

Bellahcène A, Castronovo V, Ogbureke KUE, Fisher LW, Fedarko NS (2008) Small integrinbinding ligand N-linked glycoproteins (SIBLINGs): multifunctional proteins in cancer. Nat Rev Cancer 8: 212-226.

Bento L, Zhang Z, Imai A, Nör F, Dong Z, Shi S, Araujo F, Nör J (2013) Endothelial differentiation of SHED requires MEK1/ERK signaling. J Dent Res 92: 51-57.

Bernabe E, Marcenes W, Hernandez CR, Bailey J, Abreu LG, Alipour V, Amini S, Arabloo J, Arefi Z, Arora A, Ayanore MA, Bärnighausen TW, Bijani A, Cho DY, Chu DT, Crowe CS, Demoz GT, Demsie DG, Dibaji Forooshani ZS, Du M, El Tantawi M, Fischer F, Folayan MO, Futran ND, Geramo YCD, Haj-Mirzaian A, Hariyani N, Hasanzadeh A, Hassanipour S, Hay SI, Hole MK, Hostiuc S, Ilic MD, James SL, Kalhor R, Kemmer L, Keramati M, Khader YS, Kisa S, Kisa A, Koyanagi A, Lalloo R, Le Nguyen Q, London SD, Manohar ND, Massenburg BB, Mathur MR, Meles HG, Mestrovic T, Mohammadian-Hafshejani A, Mohammadpourhodki R, Mokdad AH, Morrison SD, Nazari J, Nguyen TH, Nguyen CT, Nixon MR, Olagunju TO, Pakshir K, Pathak M, Rabiee N, Rafiei A, Ramezanzadeh K, Rios-Blancas MJ, Roro EM, Sabour S, Samy AM, Sawhney M, Schwendicke F, Shhmadi F, Shaikh MA, Stein C, Tovani-Palone MR, Tran BX, Unnikrishnan B, Vu GT, Vukovic A, Warouw TSS, Zaidi Z, Zhang ZJ, Kassebaum NJ (2020) Global, regional, and national levels and trends 
in burden of oral conditions from 1990 to 2017: a systematic analysis for the global burden of disease 2017 study. J Dent Res 99: 362-373.

Bluteau G, Luder HU, De Bari C, Mitsiadis TA (2008) Stem cells for tooth engineering. Eur Cell Mater 16: 1-9.

Burke FJ, Lucarotti PS (2009) How long do direct restorations placed within the general dental services in England and Wales survive? Br Dent J 206: 1-5.

Cable J, Fuchs E, Weissman I, Jasper H, Glass D, Rando TA, Blau H, Debnath S, Oliva A, Park S, Passegué E, Kim C, Krasnow MA (2020) Adult stem cells and regenerative medicine-a symposium report. Ann N Y Acad Sci 1462: 27-36.

Chai Y, Jiang X, Ito Y, Bringas P, Han J, Rowitch DH, Soriano P, McMahon AP, Sucov HM (2000) Fate of the mammalian cranial neural crest during tooth and mandibular morphogenesis. Development 127: 1671-1679.

Chaplet M, Waltregny D, Detry C, Fisher LW, Castronovo V, Bellahcène A (2006) Expression of dentin sialophosphoprotein in human prostate cancer and its correlation with tumor aggressiveness. Int J Cancer 118: 850-856.

Chen H, Gu L, Liao B, Zhou X, Cheng L, Ren B (2020) Advances of anti-caries nanomaterials. Molecules 25: 5047. DOI: 10.3390/molecules25215047.

Chen S, Rani S, Wu Y, Unterbrink A, Gu TT, Gluhak-Heinrich J, Chuang $\mathrm{HH}$, Macdougall M (2005) Differential regulation of dentin sialophosphoprotein expression by Runx2 during odontoblast cytodifferentiation. J Biol Chem 280: 29717-29727.

Chen S, Gluhak-Heinrich J, Martinez M, Li T, Wu Y, Chuang HH, Chen L, Dong J, Gay I, MacDougall M (2008) Bone morphogenetic protein 2 mediates dentin sialophosphoprotein expression and odontoblast differentiation via NF-Y signaling. J Biol Chem 283: 19359-19370.

Chen S, Gluhak-Heinrich J, Wang YH, Wu YM, Chuang HH, Chen L, Yuan GH, Dong J, Gay I, MacDougall M (2009). Runx2, Osx and Dspp in tooth development. J Dental Res 88: 904-909.

Chen XD, Dusevich V, Feng JQ, Manolgas SC, Jilka RL (2007) Extracellular matrix made by bone marrow cells facilitates expansion of marrow-derived mesenchymal progenitor cells and prevents their differentiation into osteoblasts. J Bone Miner Res 22: 1943-1956.

Chung HY, Li CC, Chia-Chan Hsu CC (2012) Characterization of the effects of 3DSS peptide on remineralized enamel in artificial saliva. J Mech Behav Biomed Mater 6: 74-79.

Cong X, Kong W (2020) Endothelial tight junctions and their regulatory signaling pathways in vascular homeostasis and disease. Cell Signal 66: 109485. DOI: 10.1016/j.cellsig.2019.109485.

Couve E, Osorio R, Schmachtenberg O (2014) Reactionary dentinogenesis and neuroimmune response in dental caries. J Dent Res 93: 788-793.
d'Aquino R, De Rosa A, Lanza V, Tirino V, Laino L, Graziano A, Desiderio V, Laino G, Papaccio G (2009) Human mandible bone defect repair by the grafting of dental pulp stem/progenitor cells and collagen sponge biocomplexes. Eur Cell Mater 18: 75-83.

de La Dure-Molla M, Philippe Fournier B, Berdal A (2015) Isolated dentinogenesis imperfecta and dentin dysplasia: revision of the classification. Eur J Hum Genet 23: 445-51.

Dong J, Gu TT, Jeffords L, MacDougall M (2005) Dentin phosphoprotein compound mutation in dentin sialophosphoprotein causes dentinogenesis imperfecta type III. Am J Med Genet A 132A: 305-309.

D'Souza RN, Cavender A, Sunavala G, Alvarez J, Ohshima T, Kulkarni AB, MacDougall M (1997) Gene expression patterns of murine dentin matrix protein 1 (Dmp1) and dentin sialophosphoprotein (DSPP) suggest distinct developmental functions in vivo. J Bone Miner Res 12: 2040-2049.

D'Souza RN, Aberg T, Gaikwad J, Cavender A, Owen M, Karsenty G, Thesleff I (1999) Cbfa1 is required for epithelial-mesenchymal interactions regulating tooth development in mice. Development 126: 2911-2920.

Du J, Lu Y, Song M, Yang L, Liu J, Chen X, Ma Y, Wang Y (2020) Effects of ERK/p38 MAPKs signaling pathways on MTA-mediated osteo/odontogenic differentiation of stem cells from apical papilla: a vitro study. BMC Oral Health 20: 50. DOI: 10.1186/ s12903-020-1016-x.

Ducy P, Zhang R, Geoffroy V, Ridall AL, Karsenty G (1997) Osf2/Cbfa1: a transcriptional activator of osteoblast differentiation. Cell 89: 747-754.

Eapen A, Ramachandran A, George A (2012) Dentin phosphoprotein (DPP) activates integrin-mediated anchorage-dependent signals in undifferentiated mesenchymal cells. J Biol Chem 287: 5211-5224.

Eapen A, Kulkarni R, Ravindran S, Ramachandran A, Sundivakkam P, Tiruppathi C, George A (2013) Dentin phosphophoryn activates Smad protein signaling through $\mathrm{Ca} 2+-$ calmodulin-dependent protein kinase II in undifferentiated mesenchymal cells. J Biol Chem 288: 8585-8595.

Figueiredo P, Sipponen MH, Lintinen K, Correia A, Kiriazis A, Yli-Kauhaluoma J, Österberg M, George A, Hirvonen J, Kostiainen MA, Santos HA (2019) Preparation and characterization of dentin phosphophoryn derived peptide-functionalized lignin nanoparticles for enhanced cellular uptake. Small 15: e1901427. DOI: 10.1002/smll.201901427.

Fisher LW, Fedarko NS (2003) Six genes expressed in bones and teeth encode the current members of the SIBLING family of proteins. Connect Tissue Res 44 Suppl 1: 33-40.

Friedenstein AJ, Chailakhjan RK, Lalykina KS (1970) The development of fibroblast colonies in monolayer cultures of guinea-pig bone marrow and spleen cells. Cell Tissue Kinet 3: 393-403.

Furger KA, Allan AL, Wilson SM, Hota C, Vantyghem SA, Postenka CO, Al-Katib W, Chambers 
AF, Alan B Tuck AB (2003) 33 integrin expression increases breast carcinoma cell responsiveness to the malignancy-enhancing effects of osteopontin. Mol Cancer Res 1: 810-819.

Gibson MP, Liu Q, Zhu Q, Lu Y, Jani P, Wang X, Liu Y, Paine ML, Snead ML, Feng JQ, Qin C (2013) Role of the NH2-terminal fragment of dentin sialophosphoprotein in dentinogenesis. Eur J Oral Sci 121: 76-85.

Gibson MP, 1, Jani P, Wang X, Lu Y, Qin C (2014) Overexpressing the NH2-terminal fragment of dentin sialophosphoprotein (DSPP) aggravates the periodontal defects in DSPP knockout mice. J Oral Biosci 56: 143-148.

Goldberg M, Smith AJ (2004) Cells and extracellular matrices of dentin and pulp: a biological basis for repair and tissue engineering. Crit Rev Oral Biol Med 15: $13-27$.

Götz M, Huttner WB (2005) The cell biology of neurogenesis. Nat Rev Mol Cell Biol 6: 777-788.

Griffin SO, Jones K, Gray SK, Malvitz DM, Gooch BF (2008) Exploring four-handed delivery and retention of resin-based sealants. J Am Dent Assoc 139: 281-289.

Gronthos S, Mankani M, Brahim J, Robey PG, Shi S (2000) Postnatal human dental pulp stem cells (DPSCs) in vitro and in vivo. Proc Natl Acad Sci U S A 97: 13625-13630.

Gronthos S, Brahim J, Li W, Fisher LW, Cherman N, Boyde A, DenBesten P, Robey PG, Shi S (2002) Stem cell properties of human dental pulp stem cells. J Dent Res 81: 531-535.

Gulseren G, Tansik G, Garifullin R, Tekinay AB, Guler MO (2019) Dentin phosphoprotein mimetic peptide nanofibers promote biomineralization. Macromol Biosci 19: e1800080. DOI: 10.1002/ mabi.201800080

Guo W, He Y, Zhang X, Lu W, Wang C, Yu H, Liu Y, Li Y, Zhou Y, Zhou J, Zhang M, Deng Z, Jin Y (2009) The use of dentin matrix scaffold and dental follicle cells for dentin regeneration. Biomaterials 30: 6708-6723.

Han S, Peng X, Ding L, Lu J, Liu Z, Wang K, Zhang L (2021) TVH-19, a synthetic peptide, induces mineralization of dental pulp cells in vitro and formation of tertiary dentin in vivo. Biochem Biophys Res Commun 534: 837-842.

Hart PS, Hart TC (2007) Disorders of human dentin. Cells Tissues Organs 186: 70-77.

He G, Ramachandran A, Dahl T, George S, Schultz D, Cookson D, Veis A, George A (2005) Phosphorylation of phosphophoryn is crucial for its function as a mediator of biomineralization. J Biol Chem 280: 33109-33114.

Higashikawa F, Eboshida A, Yokosaki Y (2007) Enhanced biological activity of polymeric osteopontin. FEBS Lett 581: 2697-2701.

Holappa H, Nieminen P, Tolva L, Lukinm PL, Alaluusua S (2006) Splicing site mutations in dentin sialophosphoprotein causing dentinogenesis imperfecta type II. Eur J Oral Sci 114: 381-384.
Hsu, CC, Chung HY, Yang JM, Shi W, Wu B (2011) Influence of 8DSS peptide on nano-mechanical behavior of human enamel. J Dent Res 90: 88-92.

Huang CC, Narayanan R, Warshawsky N, Ravindran S (2018) Dual ECM biomimetic scaffolds for dental pulp regenerative applications. Front Physiol 9: 495. DOI: 10.3389/fphys.2018.00495.

Jadlowiec J, Koch H, Zhang X, Campbell PG, Seyedain M, Sfeir C (2004) Phosphophoryn regulates the gene expression and differentiation of NIH3T3, MC3T3-E1, and human mesenchymal stem cells via the integrin/MAPK signaling pathway. J Biol Chem 279: 53323-53330.

Jadlowiec JA, Zhang X, Li J, Campbell PG, Sfeir $C$ (2006) Extracellular matrix-mediated signaling by dentin phosphophoryn involves activation of the Smad pathway independent of bone morphogenetic protein. J Biol Chem 281: 5341-5347.

Jonsson M, Fredriksson S, Jontell M, Linde A (1978) Isoelectric focusing of the phosphoprotein of rat incisor dentin in ampholine and acid $\mathrm{pH}$ gradients. Evidence for carrier ampholyte protein complexes. J Chromatogr 21: 234-42.

Kang J, FanW, Deng Q, He H, Huang F (2019) Stem cells from the apical papilla: a promising source for stem cell-based therapy. BioMed Res Int 2019: 6104738. DOI: 10.1155/2019/6104738.

Kaukua N, Shahidi MK, Konstantinidou C, Dyachuk V, Kaucka M, Furlan A, An Z, Wang L, Hultman I, Ahrlund-Richter L, Blom H, Brismar H, Lopes NA, Pachnis V, Suter U, Clevers H, Thesleff I, Sharpe P, Ernfors P, Fried K, Adameyko I (2014) Glial origin of mesenchymal stem cells in a tooth model system. Nature 513: 551-554.

Kazeminia M, Abdi A, Shohaimi S, Jalali R, VaisiRaygani A, Salari N, Mohammadi M (2020) Dental caries in primary and permanent teeth in children's worldwide, 1995 to 2019: a systematic review and meta-analysis. Head Face Med 16: 22. DOI: 10.1186/ s13005-020-00237-z.

Kida M, Tsutsumi T, Shindoh M, Ikeda H, Tadashi Ariga T (2009) De novo mutation in the DSPP gene associated with dentinogenesis imperfecta type II in a Japanese family. Eur J Oral Sci 117: 691-694.

Kim JW, Nam SH, Jang KT, Lee SH, Kim CC, Hahn SH, Hu JC, Simmer JP (2004) A novel splice acceptor mutation in the DSPP gene causing dentinogenesis imperfecta type II. Hum Genet 115: 248-254.

Kim JW, Hu JC, Lee JI, Moon SK, Kim YJ, Jang KT, Lee SH, Kim CC, Hahn SH, Simmer JP (2005) Mutational hot spot in the DSPP gene causing dentinogenesis imperfecta type II. Hum Genet 116: 186-191.

Kobuke S, Suzuki S, Hoshino H, Haruyama N, Nishimura F, Shiba H (2015) Relationship between length variations in Ser/Asp-rich repeats in phosphophoryn and in vitro precipitation of calcium phosphate. Arch Oral Biol 60: 1263-1272.

Lee B, Thirunavukkarasu K, Zhou L, Pastore L, Baldini A, Hecht J, Geoffroy V, Ducy P, Karsenty G (1997) Missense mutations abolishing DNA binding 
of the osteoblast-specific transcription factor OSF2/ CBFA1 in cleidocranial dysplasia. Nat Genet 16: $307-$ 310.

Lee JH, Seo SJ (2016) Biomedical application of dental tissue-derived induced pluripotent stem cells. Stem Cells Int 2016: 9762465. DOI: 10.1155/2016/9762465.

Lee JW, Hong J, Seymen F, Kim YJ, Kang J, Koruyucu M, Tuloglu N, Bayrak S, Song JS, Shin TJ, Hyun HK, Kim YJ, Lee JC, Park JC, Hu J, Simmer J, Kim JW (2019) Novel frameshift mutations in DSPP cause dentin dysplasia type II. Oral Dis 25: 2044-2046.

Lee KE, Kang HY, Lee SK, Yoo SH, Lee JC, Hwang YH, Nam KH, Kim JS, Park JC, Kim JW (2011) Novel dentin phosphoprotein frameshift mutations in dentinogenesis imperfecta type II. Clin Genet 79: 378-384.

Lee SK, Hu JCC, Lee KE, Simmer JP, Kim JW (2008) A dentin sialophosphoprotein mutation that partially disrupts a splice acceptor site causes type II dentin dysplasia. J Endod 34: 1470-1473.

Lee SK, Lee KE, Hwang YH, Kida M, Tsutsumi T, Ariga T, Park JC, Kim JW (2011) Identification of the DSPP mutation in a new kindred and phenotypegenotype correlation. Oral Dis 17: 314-319.

Lee SK, Lee KE, Song SJ, Hyun HK, Lee SH, Kim JW (2013) A DSPP mutation causing dentinogenesis imperfecta and characterization of the mutational effect. Biomed Res Int 2013: 948181. DOI: $10.1155 / 2013 / 948181$.

Lee SY, Kim SY, Park SH, Kim JJ, Jang JH, Kim EC (2012) Effects of recombinant dentin sialoprotein in dental pulp cells. J Dent Res 91: 407-412.

Li D, Du X, Zhang R, Shen B, Huang Y, Valenzuela RK, Wang B, Zhao H, Liu Z, Li J, Xu Z, Gao L, Ma J (2012) Mutation identification of the DSPP in a Chinese family with DGI-II and an up-to-date bioinformatic analysis. Genomics 99: 220-226.

Li F, Liu Y, Liu H, Yang J, Zhang F, Feng H (2017) Phenotype and genotype analyses in seven families with dentinogenesis imperfecta or dentin dysplasia. Oral Dis 23: 360-366.

Li W, Chen L, Chen Z, Wu L, Feng J, Wang F, Shoff L, Li X, Donly KJ, MacDougall M, Chen S (2017) Dentin sialoprotein facilitates dental mesenchymal cell differentiation and dentin formation. Sci Rep 7: 300. DOI: 10.1038/s41598-017-00339-w.

Li WX, Peng H, Yang L, Hao QQ, Sun W, Ji F, Guo WW, Yang SM (2018) Familial nonsyndromic hearing loss with incomplete partition type II caused by novel DSPP gene mutations. Acta Otolaryngol 138: 685-690.

Liang T, Zhang H, Xu Q, Wang S, Qin C, Lu Y (2019) Mutant dentin sialophosphoprotein causes dentinogenesis imperfecta. J Dent Res 98: 912-919.

Linde A, Goldberg M (1993) Dentinogenesis (review) Crit Rev Oral Biol Med 4: 679-728.

Liu Y, Huang Y, Gao J, Li S, Zhao X, Zhang X (2016) Identification of a novel mutation of DSPP gene in a Chinese family affected with dentinogenesis imperfecta shields type II. Zhonghua Yi Xue Yi Chuan Xue Za Zhi 33: 34-37.
Lopez-Cazaux S, Bluteau G, Magne D, Lieubeau B, Guicheux J, Alliot-Licht B (2006) Culture medium modulates the behavior of human dental pulpderived cells: technical note. Eur Cell Mater 11:35-42.

MacDougall M, Simmons D, Luan X, Nydegger J, Feng J, Gu TT (1997) Dentin phosphoprotein and dentin sialoprotein are cleavage products expressed from a single transcript coded by a gene on human chromosome 4 . Dentin phosphoprotein DNA sequence determination. J Biol Chem 272: 835-842.

Malmgren B, Lindskog S, Elgadi A, Norgren S (2004) Clinical, histopathologic, and genetic investigation in two large families with dentinogenesis imperfecta type II. Hum Genet 114: 491-498.

Marschall VZ, Fisher LW (2008) Dentin matrix protein-1 isoforms promote differential cell attachment and migration J Biol Chem 283: 3273032740 .

Marschall VZ, Fisher LW (2010) Dentin sialophosphoprotein (DSPP) is cleaved into its two natural dentin matrix products by three isoforms of bone morphogenetic protein-1 (BMP1). Matrix Biol 29: 295-303.

Martens W, Sanen K, Georgiou M, Struys T, Bronckaers A, Ameloot M, Phillips J, Lambrichts I (2014) Human dental pulp stem cells can differentiate into Schwann cells and promote and guide neurite outgrowth in an aligned tissue-engineered collagen construct in vitro. FASEB J 28: 1634-1643.

McKnight DA, Simmer JP, Hart PS, Hart TC, Fisher LW (2008a) Overlapping DSPP mutations cause dentin dysplasia and dentinogenesis imperfecta. J Dent Res 87: 1108-1111.

McKnight DA, Hart PS, Hart TC, Hartsfield JK, Wilson A, Wright JT, Fisher LW (2008b) A comprehensive analysis of normal variation and disease-causing mutations in the human DSPP gene. Hum Mutat 29: 1392-404.

Méndez-Ferrer S, Bonnet D, Steensma DP, Hasserjian RP, Ghobrial IM, Gribben JG, Andreeff M, Krause DS (2020) Bone marrow niches in haematological malignancies. Nat Rev Cancer 20: 285-298.

Miran S, Mitsiadis TA, Pagella P (2016) Innovative dental stem cell-based research approaches: the future of dentistry. Stem Cells Int 2016: 7231038. DOI: 10.1155/2016/7231038.

Mitsiadis TA, Orsini G, Jimenez-Rojo L (2015) Stem cell-based approaches in dentistry. Eur Cell Mater 30: 248-257.

Miura M, Gronthos S, Zhao M, Lu B, Fisher LW, Robey PG, Shi S (2003) SHED: stem cells from human exfoliated deciduous teeth. Proc Natl Acad Sci U S A 100: 5807-5812.

Miyazaki T, Kanatani N, Rokutanda S, Yoshida C, Toyosawa S, Nakamura R, Takada S, Komori T (2008) Inhibition of the terminal differentiation of odontoblasts and their trans-differentiation into osteoblasts in Runx2 transgenic mice. Arch Histol Cytol 71: 131-146. 
Morrison SJ, Spradling AC (2008) Stem cells and niches: mechanisms that promote stem cell maintenance throughout life. Cell 132: 598-611.

Morsczeck C, Gotz W, Schierholz J, Zeilhofer F, Kuhn U, Mohl C, Sippel C, Hoffmann KH (2005) Isolation of precursor cells (PCs) from human dental follicle of wisdom teeth. Matrix Biol 24:155-165.

Nada OA, El Backly RM (2018) Stem cells from the apical papilla (SCAP) as a tool for endogenous tissue regeneration. Front Bioeng Biotechnol 6: 103. DOI: 10.3389/fbioe.2018.00103.

Nakashima M (2005) Bone morphogenetic proteins in dentin regeneration for potential use in endodontic therapy. Cytokine Growth Factor Rev 16: 369-376.

Nanci A (2012) Ten Cate's oral histology: development, structure, and function (8th edition). Mosby, USA. pp: 1-13.

Neves VCM, Sharpe PT (2018) Regulation of reactionary dentine formation. J Dent Res 97: 416-422.

Ni SL, Zhang J, Liu X, Li XW, Sun YJ, Zhang X, Wang L, Lu JJ, Cui Y, Zheng CY, Han B, Sun HC (2018) Effects of human bone morphogenetic protein 2 (hBMP2) on tertiary dentin formation. Am J Transl Res 10: 2868-2876.

Nieminen P, Papagiannoulis-Lascarides L, Waltimo-Siren J, Ollila P, Karjalainen S, Arte S, Veerkamp J, Walton VT, Küstner EC, Siltanen T, Holappa H, Lukinm PL, Alaluusua S (2011) Frameshift mutations in dentin phosphoprotein and dependence of dentin disease phenotype on mutation location. J Bone Miner Res 26: 873-880.

Ozer A, Yuan GH, Yang GB, Wang F, Li W, Yang Y, Guo F, Gao QP, Shoff L, Chen Z, Gay I, Donly KJ, MacDougall M, Chen S (2013) Domain of dentine sialoprotein mediates proliferation and differentiation of human periodontal ligament stem cells. Plos One 8: e81655. DOI: 10.1371/journal. pone.0081655.

Paine ML, Luo W, Wang HJ, Bringas P Jr, Ngan AY, Miklus VG, Zhu DH, MacDougall M, White SN, Snead ML (2005) Dentin phosphoprotein overexpression during amelogenesis. J Biol Chem 280: 31991-31998.

Perry JM, Li L (2007) Disrupting the stem cell niche: good seeds in bad soil. Cell 129: 1045-1047.

Pisciotta A, Riccio M, Carnevale G, Lu A, De Biasi S, Gibellini L, La Sala GB, Bruzzesi G, Ferrari A, Huard J, De Pol A (2015) Stem cells isolated from human dental pulp and amniotic fluid improve skeletal muscle histopathology in mdx/SCID mice. Stem Cell Res Ther 6: 156. DOI: 10.1186/s13287-0150141-y.

Pittenger MF, Mackay AM, Beck SC, Jaiswal RK, Douglas R, Mosca JD, Moorman MA, Simonetti DW, Craig S, Marshak DR (1999) Multilineage potential of adult human mesenchymal stem cells. Science $\mathbf{2 8 4}$ 143-147.

Porntaveetus T, Nowwarote N, Osathanon T, Theerapanon T, Pavasant P, Boonprakong L, Sanon K, Srisawasdi S, Suphapeetiporn K, Shotelersuk V
(2019) Compromised alveolar bone cells in a patient with dentinogenesis imperfecta caused by DSPP mutation. Clin Oral Investig 23: 303-313.

Prince CW, Dickie D, Krumdieck CL (1991) Osteopontin, a substrate for transglutaminase and factor XIII activity. Biochem Biophys Res Commun 177: 1205-1210.

Qin C, Cook RG, Orkiszewski RS, Butler WT (2001) Identification and characterization of the carboxyl-terminal region of rat dentin sialoprotein. J Biol Chem 276: 904-909.

Qin C, Brunn JC, Cadena E, Ridall A, Tsujigiwa H, Nagatsuka H, Nagai N, Butler WT (2002) The expression of dentin sialophosphoprotein gene in bone. J Dent Res 81: 392-394.

Rajpar MH, Koch MJ, Davies RM, Mellody KT, Kielty CM, Dixon MJ (2002) Mutation of the signal peptide region of the bicistronic gene DSPP affects translocation to the endoplasmic reticulum and results in defective dentine biomineralization. Hum Mol Genet 11: 2559-2565.

Rangaswami H, Bulbule A, Kundu GC (2006) Osteopontin: role in cell signaling and cancer progression. Trends Cell Biol 16: 79-87.

Ravindran S, Snee PT, Ramachandran A, George A (2013) Acidic domain in dentin phosphophoryn facilitates cellular uptake. J Biol Chem 288: 16098-109.

Ruch JV (1985) Odontoblast differentiation and the formation of the odontoblast layer. J Dent Res 64: 489-498.

Saoud TMA, Ricucci D, Lin LM, Gaengler P (2016) Regeneration and repair in endodontics-a special issue of the regenerative endodontics-a new era in clinical endodontics. Dent J (Basel) 4: 3. DOI: 10.3390/ dj4010003.

Seo BM, Miura M, Gronthos S, Bartold PM, Batouli S, Brahim J, Young M, Robey PG, Wang CY, Shi S (2004) Investigation of multipotent postnatal stem cells from human periodontal ligament. Lancet 364: 149-155.

Shi S, Gronthos S (2003) Perivascular niche of postnatal mesenchymal stem cells in human bone marrow and dental pulp. J Bone Miner Res 18: 696704.

Sonoyama W, Liu Y, Yamaza T, Tuan RS, Wang S, Shi S, Huang GT (2008) Characterization of the apical papilla and its residing stem cells from human immature permanent teeth: a pilot study. J Endod 34: 166-171.

Song YL, Wang CN, Fan MW, Su B, Z Bian Z (2008) Dentin phosphoprotein frameshift mutations in hereditary dentin disorders and their variation patterns in normal human population. J Med Genet 45: 457-464.

Sreenath T, Thyagarajan T, Hall B, Longenecker G, D'Souza R, Hong S, Wright JT, MacDougall M, Sauk J, Ashok B Kulkarni AB (2003) Dentin sialophosphoprotein knockout mouse teeth display widened predentin zone and develop defective dentin mineralization similar to human dentinogenesis imperfecta type III. J Biol Chem 278: 24874-24880. 
Steiglitz BM, Ayala M, Narayanan K, George A, Greenspan DS (2004) Bone morphogenetic protein-1/ Tolloid-like proteinases process dentin matrix protein-1. J Biol Chem 279: 980-986.

Sui B, Chen C, Kou X, Li B, Xuan K, Shi S, Jin Y (2019) Pulp stem cell-mediated functional pulp regeneration. J Dent Res 98: 27-35.

Suzuki S, Sreenath T, Haruyama N, Honeycutt C, Terse A, Cho A, Kohler T, Müller R, Goldberg M, Kulkarni AB (2009) Dentin sialoprotein and dentin phosphoprotein have distinct roles in dentin mineralization. Matrix Biol 28: 221-229.

Suzuki S, Kobuke S, Haruyama N, Hoshino H, Kulkarni AB, Nishimura F (2014) Adhesive and migratory effects of phosphophoryn are modulated by flanking peptides of the integrin binding motif. PLoS One 9: e112490. DOI: 10.1371/journal. pone.0112490.

Suzuki S, Nakanishi J, Yoshida K, Shiba H (2016) Dentin sialophosphoprotein is a potentially latent bioactive protein in dentin. J Oral Biosci 58: 134-142.

Teramoto H, Castellone MD, Malek RL, Letwin N, Frank B, Gutkind JS, Lee NH (2005) Autocrine activation of an osteopontin-CD44-Rac pathway enhances invasion and transformation by H-RasV12. Oncogene 24: 489-501.

Thesleff I (2003) Epithelial-mesenchymal signaling regulating tooth morphogenesis. J Cell Sci 116: 16471648.

Tirino V, Paino F, De Rosa A, Papaccio G (2012) Identification, isolation, characterization, and banking of human dental pulp stem cells. Methods Mol Biol 879: 443-463.

Tsuchiya S, Simmer JP, Hu JC, Richardson AS, Yamakoshi F, Yamakoshi Y (2011) Astacin proteases cleave dentin sialophosphoprotein (Dspp) to generate dentin phosphoprotein (Dpp). J Bone Miner Res 26: 220-228.

Tziafas D, Smith AJ, Lesot H (2000) Designing new treatment strategies in vital pulp therapy. J Dent 28: 77-92.

Vijaykumar A, Dyrkacz P, Vidovic-Zdrilic I, Maye P, Mina M (2020) Expression of BSP-GFPtpz transgene during osteogenesis and reparative dentinogenesis. J Dent Res 99: 89-97.

Vidovic I, Banerjee A, Fatahi R, Matthews BG, Dyment NA, Kalajzic I, Mina M (2017) $\alpha$ SMAexpressing perivascular cells represent dental pulp progenitors in vivo. J Dent Res 96: 323-330.

Waddington RJ, Youde SJ, Lee CP, Sloan AJ (2009) Isolation of distinct progenitor stem cell populations from dental pulp. Cells Tissues Organs 189: 268-274.

Walker JV, Zhuang H, Singer D, Illsley CS, Kok WL, Sivaraj KK, Gao Y, Bolton C, Liu Y, Zhao M, Grayson PRC, Wang S, Karbanová J, Lee T, Ardu S, Lai Q, Liu J, Kassem M, Chen S, Yang K, Bai Y, Tredwin C, Zambon AC, Corbeil D, Adams R, Abdallah BM, Hu B (2019) Transit amplifying cells coordinate mouse incisor mesenchymal stem cell activation. Nat Commun 10: 3596. DOI: 10.1038/ s41467-019-11611-0.
Wan C, Yuan G, Luo D, Zhang L, Lin H, Liu H, Chen L, Yang G, Chen S, Chen Z (2016) The dentin sialoprotein (DSP) domain regulates dental mesenchymal cell differentiation through a novel surface receptor. Sci Rep 6: 29666. DOI: 10.1038/ srep29666.

Wang HY, Hou YN, Cui YX, Huang YF, Shi YC, Xia XY, Lu HY, Wang YH, Li XJ (2009) A novel splice site mutation in the dentin sialophosphoprotein gene in a Chinese family with dentinogenesis imperfecta type II. Mutat Res 662: 22-27. DOI: 10.1016/j. mrfmmm.2008.11.019.

Wang L, Dorn P, Zeinali S, Froment L, Berezowska S, Kocher GJ, Alves MP, Brügger M, Esteves BIO, Blank F, Wotzkow C, Steiner S, Amacker M, Peng RW, Marti TM, Guenat OT, Bode PK, Moehrlen U, Schmid RA, Hall SRR (2020a) CD90(+)CD146(+) identifies a pulmonary mesenchymal cell subtype with both immune modulatory and perivascularlike function in postnatal human lung. Am J Physiol Lung Cell Mol Physiol 318: L813-L830. DOI: 10.1152/ ajplung.00146.2019.

Wang Y, Zhu M, Zhu XX (2020b) Functional fillers for dental resin composites. Acta Biomater 122: 50-65.

White SN, Paine ML, Ngan AYW, Miklus VG, Luo W, Wang HJ, Malcolm L. Snead, ML (2007) Ectopic expression of dentin sialoprotein during amelogenesis hardens bulk enamel. J Biol Chem 282: 5340-5345.

Wilkinson AC, Igarashi KJ, Nakauchi H (2020) Haematopoietic stem cell self-renewal in vivo and ex vivo. Nat Rev Genet 21: 541-554.

Witkop Jr CJ (1975) Hereditary defects of dentin. Dent Clin North Am 19: 25-45.

Xiao S, Yu C, Chou X, Yuan W, Wang Y, Bu L, Fu G, Qian M, Yang J, Shi Y, Hu L, Han B, Wang Z, Huang W, Liu J, Chen Z, Zhao G, Kong X (2001) Dentinogenesis imperfecta 1 with or without progressive hearing loss is associated with distinct mutations in DSPP. Nat Genet 27: 201-204.

Yamakoshi Y, Hu JC, Fukae M, Zhang H, Simmer JP (2005) Dentin glycoprotein: the protein in the middle of the dentin sialophosphoprotein chimera. J Biol Chem 280: 17472-17479.

Yamakoshi Y, Hu JC, Iwata T, Kobayashi K, Fukae M, Simmer JP (2006) Dentin sialophosphoprotein is processed by MMP-2 and MMP-20 in vitro and in vivo. J Biol Chem 281: 38235-38243.

Yamanaka S (2020) Pluripotent stem cell-based cell therapy-promise and challenges. Cell Stem Cell 27: 523-531.

Yamaza T, Kentaro A, Chen C, Liu Y, Shi Y, Gronthos S, Wang S, Shi S (2010) Immunomodulatory properties of stem cells from human exfoliated deciduous teeth. Stem Cell Res Ther 1: 5. DOI: $10.1186 /$ scrt5.

Yang J, Kawasaki K, Lee M, Reid BM, Nunez SM, Choi M, Seymen F, Koruyucu M, Kasimoglu Y, Estrella-Yuson N, Lin BP, Simmer JP, Hu JC (2015) The dentin phosphoprotein repeat region and inherited defects of dentin. Mol Genet Genomic Med 4: 28-38. 
Yang JW, Shin YY, Seo Y, Kim HS (2020b) Therapeutic functions of stem cells from oral cavity: an update. Int J Mol Sci 21: 4389. DOI: 10.3390/ ijms21124389.

Yang SY, Choi JW, Kim KM, Kwon JS (2020a) Prevention of secondary caries using resin-based pit and fissure sealants containing hydrated calcium silicate. Polymers (Basel) 12: 1200. DOI: 10.3390/ polym12051200.

Yang X, Ma Y, Guo W, Yang B, Tian W (2019) Stem cells from human exfoliated deciduous teeth as an alternative cell source in bio-root regeneration. Theranostics 9: 2694-2711.

Yin Y, Garcia MR, Novak AJ, Saunders AM, Ank RS, Nam AS, Fisher LW (2018) Surf4 (Erv29p) binds amino-terminal tripeptide motifs of soluble cargo proteins with different affinities, enabling prioritization of their exit from the endoplasmic reticulum. PLoS Biol 16: e2005140. DOI: 10.1371/ journal.pbio.2005140.

Yuan G, Yang G, Song G, Chen Z, Chen S (2012) Immunohistochemical localization of the $\mathrm{NH}(2)$ terminal and $\mathrm{COOH}$-terminal fragments of dentin sialoprotein in mouse teeth. Cell Tissue Res 349: 605-614.

Yuan G, Chen L, Feng JS, Yang G, Ni Q, Xu XP, Wan C, Lindsey M, Donly KJ, MacDougall M, Chen Z, Chen S (2017) Dentin sialoprotein is a novel substrate of matrix metalloproteinase 9 in vitro and in vivo. Sci Rep 7: 42449. DOI: 10.1038/srep42449.

Zaugg LK, Banu A, Walther AR, Chandrasekaran D, Babb RC, Salzlechner C, Hedegrd MAB, Gentleman E, Sharpe PT (2020) Translation approach for dentine regeneration using GSK-3 antagonists. J Dent Res 99: 544-551.
Zhang H, Liu P, Wang S, Liu C, Jani P, Lu Y, Qin C (2016) Transgenic expression of dentin phosphoprotein inhibits skeletal development. Eur J Histochem 60: 2587. DOI: 10.4081/ejh.2016.2587.

Zhang H, Xie X, Liu P, Liang T, Lu Y, Chunlin Qin C (2018) Transgenic expression of dentin phosphoprotein (DPP) partially rescued the dentin defects of DSPP-null mice. PLoS One 13: e0195854. DOI: 10.1371/journal.pone.0195854.

Zhang J, Wang J, Ma Y, Du W, Zhao S, Zhang Z, Zhang X, Liu Y, Xiao H, Wang H, Jin L, Liu J (2011) A novel splicing mutation alters DSPP transcription and leads to dentinogenesis imperfecta type II. PLoS One 6: e27982. DOI: 10.1371/journal.pone.0027982.

Zhang X, Zhao J, Li C, Gao S, Qiu C, Liu P, Wu G, Qiang B, Lo WH, Shen Y (2001) DSPP mutation in dentinogenesis imperfecta shields type II. Nat Genet 27: 151-152.

Zhang X, Chen L, Liu J, Zhao Z, Qu E, Wang X, Chang W, Xu C, Wang QK, Liu M (2007) A novel DSPP mutation is associated with type II dentinogenesis imperfecta in a Chinese family. BMC Med Genet 8: 52. DOI: 10.1186/1471-2350-8-52.

Zhu Q, Gibson MP, Liu Q, Liu Y, Lu Y, Wang X, Feng JQ, Qin C (2012) Proteolytic processing of dentin sialophosphoprotein (DSPP) is essential to dentinogenesis. J Biol Chem 287: 30426-30435.

Editor's note: There were no questions from reviewers for this paper, therefore there is no Discussion with Reviewers section. The Scientific Editor responsible for this paper was Thimios Mitsiadis. 